This PDF is a selection from an out-of-print volume from the National Bureau of Economic Research

Volume Title: International Policy Coordination and Exchange Rate Fluctuations

Volume Author/Editor: William H. Branson, Jacob A. Frenkel, and Morris Goldstein, editors

Volume Publisher: University of Chicago Press

Volume ISBN: 0-226-07141-3

Volume URL: http://www.nber.org/books/bran90-1

Conference Date: October 27-29, 1988

Publication Date: January 1990

Chapter Title: The Rationale for, and Effects of, International Economic Policy Coordination

Chapter Author: Jacob Frenkel, Morris Goldstein, Paul Masson

Chapter URL: http://www.nber.org/chapters/c6945

Chapter pages in book: (p. 9 - 62) 


\title{
The Rationale for, and Effects of, International Economic Policy Coordination
}

\author{
Jacob A. Frenkel, Morris Goldstein, and Paul R. Masson
}

Coordination of macroeconomic policies is certainly not easy; maybe it is impossible But in its absence, I suspect nationalistic solutions will be sought-trade barriers, capital controls, and dual exchange-rate systems. War among nations with these weapons is likely to be mutually destructive. Eventually, they, too, would evoke agitation for international coordination.

James Tobin $(1987,68)$

I believe that many of the claimed advantages of cooperation and coordination are wrong, that there are substantial risks and disadvantages to the types of coordination that are envisioned, and that an emphasis on international coordination can distract attention from the necessary changes in domestic policy.

Martin Feldstein $(1988,3)$

\subsection{Introduction}

This paper discusses the rationale and mechanisms for, and the effects of, international coordination of economic policies. Coordination is defined here, following Wallich $(1984,85)$, as " a significant modification of national policies in recognition of international economic interdependence.", The existence of a number of comprehensive surveys of the literature on coordination makes the task easier. ${ }^{2}$ This discussion can, therefore, be selective and focus on a number of key issues that impinge on the advisability and practicality of strengthening policy coordination among the larger industrial countries.

Jacob A. Frenkel is the Economic Counsellor and Director of Research at the International Monetary Fund, and a research associate of the National Bureau of Economic Research. Morris Goldstein is Deputy Director of the Research Department of the International Monetary Fund. Paul R. Masson is an Advisor in the Research Department of the International Monetary Fund, and a research affiliate of the National Bureau of Economic Research.

The views expressed are the authors' alone and do not represent the views of the International Monetary Fund. 
This paper is organized as follows. Section 1.2 covers economic policy coordination in the widest sense and addresses various dimensions of the rationale for, and scope of, coordination. The terrain covered includes the applicability of the "invisible hand" paradigm to decentralized economic policy decisions, barriers to coordination, the range and specificity of policies to be coordinated, the frequency of coordination, and the number of participants to be included in the coordination exercise. Section 1.3 narrows the discussion to monetary and fiscal policies and turns to the mechanisms or methods of coordination. The emphasis here is on the two broad issues of rules versus discretion and of single-indicator versus multiple-indicator approaches, ${ }^{3} \mathrm{~A}$ brief discussion is also included on the use of indicators in the ongoing Group of Seven (G-7) coordination process.

Section 1.4 confronts the problem of how to infer the effects of coordination. A number of empirical experiments are carried out using a global macroeconomic model (MULTIMOD) developed in the International Monetary Fund. The policies considered include nominal GNP or money targeting, "smoothing" rules for monetary and fiscal policy that imply only modest international coordination, and more activist "target-zone" proposals that place greater international conditions on national authorities in the conduct of monetary and/or fiscal policies. In one set of "historical" simulations, we compare the results of simulated policies to the actual evolution of the world economy over the 1974-87 period. In the other set of simulations, we analyze the effects of various single shocks to particular behavioral relationships under alternative policy rules.

\subsection{Rationale for and Scope of Coordination}

The most logical starting point is to ask why international policy coordination would be beneficial in the first place. After all, if in the domestic economy the working of the invisible hand under pure competition translates independent decentralized decisions into a social optimum, why should not the same principle apply to policy decisions by countries in the world economy?

The answer is that economic policy actions, particularly those of larger countries, create quantitatively significant spillover effects or externalities for other countries, and that a global optimum requires that such externalities be taken into account in the decision-making calculus ${ }^{4}$ Coordination is then best seen as a facilitating mechanism for internalizing these externalities.

This conclusion can perhaps be better appreciated by emphasizing the departures from the competitive model in today's global economy. Cooper (1987) has identified several such departures, and his analysis merits some extension here.

Unlike the atomistic economic agents of the competitive model who base their consumption and production decisions on prices that are beyond their control, larger countries exercise a certain degree of influence over prices, 
including the real exchange rate. This of course raises the specter that they will manipulate such prices to their own advantage and at the expense of others. Two examples are frequently cited - one dealing with inflation, and the other with real output and employment. Under floating rates, a Mundellian (1971) policy mix of tight monetary and loose fiscal policy allows an appreciated currency to enhance a country's disinflationary policy strategy — but at the cost of making it harder for trading partners to realize their own disinflation targets. Similarly, under conditions of high capital mobility and sticky nominal wages, a monetary expansion under floating rates leads to a real depreciation and to an expansion of output and employment at home. But the flip side of the coin is that output and employment contract abroad. ${ }^{5}$ Seen in this light, the role of coordination is to prevent-or to minimize-such intentional as well as unintentional "beggar-thy-neighbor" practices. Most international monetary constitutions have injunctions against "manipulating" exchange rates or international reserves.

The existence of public goods constitutes a second important point of departure from the competitive model.

When there are $\mathrm{N}$ currencies, there can be only $N-1$ independent exchange rate targets. Similarly, not all countries can achieve independently set targets for current account surpluses. Adherents of decentralized policymakingsometimes rather inappropriately labelled the "German school"-argue that such inconsistencies provide no justification for coordination. Much as in the competitive model, the economic system will generate signals - in the form of changes in exchange rates, interest rates, prices, and incomes-that will lead to an adjustment of targets such that they eventually become consistent. If, however, the path to consistency involves large swings in real exchange rates, or even more problematically, the imposition of restrictions on trade and capital flows, then reliance on decentralized policymaking may not be globally optimal. Implicit in this conclusion is the notion that a certain degree of stability in real exchange rates and an open international trading and financial system are valued in and of themselves as public goods (in contrast, the market signals that resolve supply/demand inconsistencies in the competitive model, are not regarded as public goods). If that is accepted, there is a positive role for coordination, both to identify target inconsistencies at an early stage and to resolve them in ways that do not produce too little of the public good(s). ${ }^{6}$ It is of course possible for groups of countries who value the public good highly to attempt to obtain more of it by setting up "regional" zones of exchange rate stability or of free trade, and some have done just that (including the establishment of the European Monetary System [EMS]). ${ }^{7}$ But the essence of a public good is that it will tend to be undersupplied so long as some large suppliers or users act in a decentralized fashion.

Once the realm of atomistic competitors is left and that of nontrivial spillovers of policies is entered - be it via goods, asset, or labor markets - the possibility arises that choices made independently by national governments 
would not be as effective in achieving their objectives as policies that are coordinated with other governments. ${ }^{8}$ Whereas any single country acting alone may be reluctant to follow expansionary policies designed to counter a global deflationary shock for fear of unduly worsening its external balance, coordinated expansion by many countries will loosen the external constraint and permit each country to move closer to internal balance. In addition, coordination may assist the policymaking process by mobilizing peer pressure to help provide governments with the political will to make difficult choices in the face of opposition from domestic pressure groups. The success of Weight Watchers provides an intuitive parallel: while overweight individuals know what needs to be done to meet their targets and could in principle do it entirely on their own, many apparently find it helpful to subject themselves to peer pressure and to engage the moral support of others in like circumstances.

All of this establishes a presumption that there can be valid reasons for deviating from the tradition of decentralized decision-making when it comes to economic policy, that is, that there is scope for coordination. This presumption is reinforced by two empirical observations. The first is that the world economy of 1990 is considerably more open and integrated than that of 1950 , or 1960 , or even of 1970 . Not only have simple ratios of imports or exports to GNP increased but also — and probably more fundamentally — global capital markets have become more integrated (Fischer 1988; Frenkel 1983, 1986). With larger spillovers, there is more at stake in how one manages interdependence. Second, there is by now widespread recognition that the insulating properties of floating exchange rates are more modest than was suspected prior to their introduction in $1973 .{ }^{9}$

But a presumption that cooperation could be beneficial is not the same as a guarantee-nor does it preclude the existence of sometimes formidable obstacles to its implementation.

Suppose national policymakers have a predilection for inflationary policies but are restrained from implementing them by the concern that relatively expansionary monetary policy will bring on a devaluation (or depreciation). Yet, as outlined by Rogoff (1985), if all countries pursue such inflationary policies simultaneously, none has to worry about the threat of devaluation. Here, coordination may actually weaken discipline by easing the balance of payments constraint. In a similar vein, as noted by Feldstein (1988) there is the potential risk that a coordinated attempt to stabilize a pattern of nominal or real exchange rates could take place in an inappropriately high aggregate rate of inflation. Equally troublesome would be a coordination of fiscal policies that yielded an aggregate fiscal deficit for the larger countries that put undue upward pressure on world interest rates. The basic point is straightforward: there is nothing in the coordination process in and of itself that reduces the importance of sound macroeconomic policies (Bockelmann 1988). There can be coordination around good policies and coordination around bad ones-just as with the exchange rate regime, where there are good fixes and bad fixes, 
and good floats and bad floats (Frenkel 1985). Welfare improvements are not automatic.

It is only realistic, too, to acknowledge that there are barriers to the exercise of coordination. Four of the more prominent ones are worth mentioning. First, international policy bargains that involve shared objectives can be frustrated if some policy instruments are treated as objectives in themselves. Schultze (1988), for example, offers the view that it would have been difficult to have reached a bargain on target zones for exchange rates in the early 1980s given President Reagan's twin commitments to increasing defense spending and cutting taxes. In some other countries, the constraints on policy instruments may lie in different areas-including structural policies_-but the implications are the same.

Second, there can at times be sharp disagreements among countries about the effects that policy changes have on policy targets. In some cases, these differences may extend beyond the size to even the sign of various policy impact multipliers. ${ }^{10}$ The harder it is to agree on how the world works, the harder it is to reach agreement on a jointly designed set of policies.

Third, while most countries have experienced a marked increase in openness over the past few decades, there remain huge cross-country differences in the degree of interdependence. Large countries-the United States being the classic case in point-are generally less affected than small countries by other countries' policies. Coordination-as Bryant (1987) has recently emphasized-is not a matter of altruism. It is rather the manifestation of mutual self-interest. To the extent that large countries are less beset by spillovers and feedbacks than small ones, the formers' incentive to coordinate on a continuous basis may be lower. ${ }^{11}$ In this regard, the high degree of trade interdependence shared by members of the EMS can be seen as a positive factor in reinforcing incentives to coordinate in that group.

Finally, as Polak (1981) has reminded us, in terms of national priorities, international bargaining typically comes after domestic bargaining. More specifically, the compromise of growth and inflation objectives at the national level may leave little room for further compromise on demand measures at the international level.

These barriers to coordination should not be overestimated. One of the clearest examples of true coordination-the Bonn Economic Summit of 1978 - occurred just when domestic bargaining over the same issues was most intense. ${ }^{12}$ The growing integration of capital markets-of which the global stock market crash of October 1987 is but one reminder-has brought the implications of interdependence home to even large countries, and continued empirical work on multicountry models should be able progressively to whittle down the margin of disagreement on the effects of policies. Still, as readers of Sherlock Holmes will be aware, sometimes the most telling clue is that the hounds didn't bark. If the scope for coordination is to expand beyond the efforts of the past, these obstacles will need to be overcome. 
Turning from the rationale to the scope for coordination, a key issue concerns the appropriate range and depth of policies to be coordinated.

The case for supporting a wide-ranging, multi-issue approach to coordination is that it increases the probability of concluding some policy bargains that benefit all parties (Putnam and Bayne 1984), that favorable spillover effects are generated across negotiating issues, and that improved economic performance today depends as much on trade and structural policies as on exchange rate and demand policies. Exhibit A is the Bonn Economic Summit of 1978 where commitments to accelerate growth by Japan and the Federal Republic of Germany were exchanged for a commitment by the United States to come to grips with its inflation and oil problems, and where agreement on macroeconomic and energy policies has been credited with reinforcing progress on the Tokyo Round of Multilateral Trade Negotiations (Putnam and Henning 1986).

The defense of a narrower approach to coordination rests on the arguments that negotiation costs rise rapidly with the spread of issues under consideration (Artis and Ostry 1986), that prospects for implementation of agreements dim as the number of jurisdictional spheres expands (i.e., finance ministers can negotiate agreements but fiscal policy is typically the responsibility of legislatures, while monetary policy is the province of independent central banks); and that heated disputes on some issues (such as the stance of monetary and fiscal policies) can frustrate the chance for agreements in other areas (like defense and foreign assistance) where coordination might be more fruitful (Feldstein 1988). In addition, a case could be made that coordination is only likely in areas where there is a consensus about the effects of common policies (Cooper 1988).

In view of these conflicting considerations, it is hard to fault present institutional practices on the range of coordination. Those practices entail high-frequency coordination on narrow issues in a multitude of forums (such as the IMF, the Organization of Economic Cooperation and Development [OECD], the Bank of International Settlements [BIS], and the General Agreement on Tariffs and Trade [GATT]) ${ }^{13}$ less frequent (say, biannual) and wider coordination at a higher level in more limited forums (such as the IMF's Interim Committee, or the G-7 major industrial countries); and even less frequent (annual), wider-yet coordination at the highest level (heads of state and of governments at the economic summits). Thus, there are occasional opportunities for multi-issue bargaining, but without the exponential increase in negotiation costs that might ensue if this were the order of the day. All in all, probably not a bad compromise.

The "depth" of coordination covers the degree of specificity and disaggregation within a given policy area. Here, two issues arise-one dealing with fiscal policy, and the other with structural policies. A strong implication of recent research is that aggregate measures, such as the central or general 
government fiscal deficit, are not likely to be a good guide to the effects of fiscal policies on macroeconomic variables such as the current account, the exchange rate, and the rate of interest (Frenkel and Razin 1987b). The reason is that such effects depend on how the deficit is altered: that is, taxes versus expenditures, expenditures on tradables versus nontradables, taxes on investment versus those on saving, fiscal action by a country with a current account surplus versus a deficit, and anticipated versus unanticipated policies. This suggests that more specificity in coordination-quite apart from its positive effect on the ability to monitor the implementation of agreed upon policies-would be desirable. It is notable that the Louvre Accord of February 1987 among the G-7 specified not only quantitative targets for budget deficits but also some quantitative guidelines for how these overall fiscal targets were to be achieved. ${ }^{14}$

In the area of structural policies, a good case can also be made for specificity-but on somewhat different grounds. Here, coordination may often best be interpreted not as the simultaneous application of the same policy instrument in different doses or directions across countries, but rather as the simultaneous application of different policy instruments ${ }^{15}$ - with each country adopting the policy best tailored to its particular structural weakness. ${ }^{16}$ In some cases, this may imply reducing impediments to labor mobility or to marketdetermined wages; in others, it may mean increasing incentives for private investment relative to those for private saving; and in still others, it may mean changes in the trade and distribution system. The simultaneous application of the policy measures across countries may be necessary to overcome the blocking tactics of domestic pressure groups and to enhance the credibility of the exercise. Again, the depth or specificity of coordination can be as relevant as the range.

Another salient issue concerns the question of when to coordinate. There has been, and continues to be, wide variation in the frequency of coordination across different forums-ranging from one-of-a-kind meetings like the 1971 Smithsonian Conference on exchange rates to the near continuous discussion and decision-making at the executive boards of the IMF and the World Bank.

One position is that, given the constraints, true coordination cannot be expected to be more than an episodic, regime-preserving effort. Dini (1988) has recently argued that international considerations still play only a small factor in policymaking, and that only at times of crisis is a common interest in coordinated action clearly recognized. ${ }^{17}$ Some might even go further and argue that the reservoir of international compromise should be conserved for situations where there is a high probability of a policy deal and where failure to reach an agreement would carry a high cost.

Our view is that both the likelihood and effectiveness of coordination will be enhanced when it is a regular, ongoing process - and for at least three reasons. First, the potential for multiperiod bargaining expands the opportunities 
for policy bargains (by facilitating, for example, phasing of policy measures). What should count in assessing the gains to coordination is the present discounted value of welfare-improving policy agreements over an extended period-not the welfare change in a single period. Second, as suggested in the game-theoretic literature, the existence of repeated bargaining strengthens the role of reputational considerations in coordination. ${ }^{18}$ In contrast, when coordination is a once-and-for-all or episodic exercise, there is a higher risk that agreed policies will never be implemented because of the much discussed problem of time inconsistency, that is, the temptation to renege on earlier policy commitments when it later becomes advantageous to do so (Kydland and Prescott 1977; Calvo 1978). To be effective, coordination agreements need to pass through the market filter of credibility, and credibility is more likely if sticking to the agreement enhances reputation, which in turn allows profitable bargains to be struck in the future. Third, once coordination is established as a routine ongoing process, there is apt to be more freedom of policy maneuver for all participants than when negotiations are conducted in a crisis atmosphere and when disagreements-which after all are inevitable-may be inappropriately seen as signaling the collapse of coordination itself. ${ }^{19}$

A final question concerns the size of the coordinating group, that is, who should coordinate. Again, existing practice does not provide a definitive answer. Among the industrial countries, we have the Group of Seven and the Group of Ten. For the developing countries, there are the Group of TwentyFour and the Group of Seventy-Seven. And in the executive board of the Fund-where industrial and developing countries alike are represented-there are twenty-two representatives of various country groupings-a Group of Twenty-Two.

Among the factors that should influence the size of the coordinating group, three would seem to stand out. First, to the extent that the raison d'être of coordination is the internalization of externalities, the group should include those countries whose policies generate the largest externalities. This argues for including the largest industrial countries. Second, there is the general proposition that the costs of negotiation, and conflicts that might endanger the continuity of the exercise, increase significantly with the number of players. This argues for a relatively small group. Third, and pointing in the opposite direction, a small group runs the risk of concluding policy agreements which are beneficial to the direct participants-but which are not satisfactory to those countries not sitting at the coordination table. ${ }^{20}$ In this connection, it is relevant that the managing director of the Fund participates in G-7 coordination meetings. Since the Fund's membership includes not only the larger industrial countries but also the smaller industrial countries, as well as most of the developing countries, one rationale for the managing director's participation is that it provides a systemic perspective and evaluation on proposed policy agreements-while still keeping the meeting small enough for administrative efficiency. 


\subsection{Mechanisms of Coordination}

This section shifts the focus from whether to coordinate to how to coordinate. More specifically, the advantages and disadvantages of alternative mechanisms of coordination are discussed, with particular attention to the issues of rules versus discretion and of single- versus multi-indicator approaches. The use of economic indicators in the ongoing G-7 coordination process is also outlined.

It is not surprising that many of the issues that emerged during the long and continuing debate on the relative merits of rules versus discretion in domestic economic policy should have resurfaced in the dialogue on international economic policy coordination. After all, the present system of managed floating, even as it has evolved since the Plaza Agreement of September 1985, is much closer to a pure discretion than to a pure rules model. In this regard, the gold standard with its automatic specie flow mechanism, the adjustable peg system with its clear implications for the subordination of domestic monetary policy to the exchange rate (except during fundamental disequilibria), the EMS with its parity grid and divergence indicator, target zone proposals with their trigger for coordination discussions whenever the actual exchange rate threatens to breach the zone, and pure floating with its complete prohibition on all official intervention in the exchange market - all can be considered less discretionary than the present exchange rate system.

Those who support a more rule-based approach to international economic policy rest their case on essentially four arguments. First, the most promising route to eliminating any excess demand for coordination in the world economy is not by increasing the supply, but rather by decreasing the demand (or the need) for coordination (Polak 1981; Kenen 1987). That decrease in demand, in turn, can best be brought about by the application of simple policy rules, such as the maintenance of a fixed exchange rate. In the process, one would eliminate-so the argument goes-most of the negotiation costs and burdensharing conflicts that are intrinsic to more discretionary systems. Second, rules are regarded as the only viable mechanism for imposing discipline on economic policymakers who might otherwise manipulate the instruments of policy for their own objectives. ${ }^{21}$ Third, rules are regarded as enhancing the predictability of policy actions and thereby improving the private sector's ability to make informed resource allocation decisions. ${ }^{22}$ Fourth, rules are seen as a way of preventing destabilizing fine-tuning, and thus of providing protection against the lack of knowledge about how the economy operates.

The main counterarguments in favor of a discretionary approach are the following. First, rule-based adjustment systems often turn out to be less automatic in practice than in theory. For example, the automaticity of the specie flow mechanism under the historical gold standard was often undermined by the proclivity of authorities to offset or sterilize the effect of gold flows (Cooper 1982; U.S. Congress 1982). 
Second, rules will impart discipline to the conduct of macroeconomic policy only to the extent that the penalties for breaking the rules are significant enough to ensure that the rules are followed. The Bretton Woods rule that countries should consult with the Fund once there was a cumulative parity change of 10 percent or more, while complied with in a technical sense, fell short in a substantive sense of its original purpose. The discussion surrounding the revision of the original Gramm-Rudman deficit reduction targets in the United States is a more recent case in point. History could in fact be seen as being just as kind to the proposition that the policy regime adjusts to the amount of discipline that countries want to have-as to the reverse (Goldstein 1980, 1984; Frenkel 1982; Frenkel and Goldstein 1986). Also, care needs to be taken to separate the effects of policy rules on economic outcomes from other influences. In this connection, the oft-made argument that the EMS was a major determinant of the 1979-85 disinflation in Europe would seem to be based on shaky ground. ${ }^{23}$

Third, it is by no means clear that rules are necessary to obtain the benefits of greater predictability of policy. For example, the practice of preannouncing money-supply targets-sometimes accompanied by announcements of public sector borrowing requirements-provides the markets with information on the authorities' policy intentions, but stops well short of a rigid rule.

Finally, while rules diminish the risk emanating from fine-tuning, they increase the risk stemming from lack of adaptability to changes in the operating environment. ${ }^{24}$ The idea of a "crawling-peg" rule based on inflation differentials drew quite a few supporters in the 1960s as the right antidote for sticky nominal exchange rates. Yet its neglect of the need for real exchange rate changes now seems more serious in light of the real economic disturbances of the early 1970s. ${ }^{25}$ More recently, the crumbling of the link between narrow monetary aggregates and the ultimate targets of monetary policy in the face of large-scale financial innovation and institutional change has reminded us anew of the limitations of policy rules.

In light of all this, there may not be any attractive alternative to conducting economic policy coordination in a judgmental way.

Even after the choice is made about coordinating via rules or discretion, there remains the decision of whether to coordinate around a single indicator or a set of indicators. ${ }^{26}$

There are two main considerations that are typically advanced to support the single-indicator approach. One is that it avoids overcoordination of policies by preserving for each country freedom of action over those policies not used to reach the single target variable. Thus, for example, if the exchange rate is the focus of coordination, monetary policy will be constrained, but other policies will be less affected. Implicit in this line of argument is the view that attempts to place many policies under international coordination will ultimately prove self-defeating and may even induce national authorities to compensate by exercising greater independence in uncoordinated policy instruments, such as trade policy (Frenkel 1975). 
The second, and probably more important, defense of a single-indicator approach is that it sends a clear signal to markets about the course of future policy. If, for example, the monetary authorities commit themselves to maintain a fixed exchange rate within a given band, then movements of the exchange rate provide an unambiguous guide for monetary policy. A similar message would derive from a nominal income target for monetary or fiscal policy, with the exchange rate left to determination of the market. In contrast, a multi-indicator approach increases the authorities' scope for discretion since they can appeal to the conflicting messages coming from different indicators. In cases where the authorities' past record of policy performance has been weak and where a single objective of policy is predominant (such as disinflation), a single-indicator framework for coordination can carry significant advantages in the battle to restore credibility to policy.

But relying on a single policy indicator can also carry substantial risks. Perhaps the most serious one is that the single indicator can send weak-or even false signals - about the need for changes in other policies that are not being coordinated. This is perhaps best illustrated by considering the problem of errant fiscal policy under a regime of fixed exchange rates or of target zones.

First, consider fixed rates. With high capital mobility, a fiscal expansion will yield an incipient positive interest rate differential, a capital inflow, and an overall balance of payments surplus - not a deficit. Here, exchange rate fixity helps to finance-and by no means disciplines--irresponsible fiscal policy (Frenkel and Goldstein 1988a). Only if and when the markets expect fiscal deficits to be monetized will they force the authorities to choose between fiscal policy adjustments and devaluation. ${ }^{27}$ The better the reputation of the authorities, the longer in coming will be the discipline of markets, that is, the exchange rate will provide only a weak and late signal for policy adjustment. In this connection, it is worth observing that whereas the EMS has produced a notable convergence of monetary policy, convergence of fiscal policy has not taken place (Tanzi and Ter-Minassian 1987; Holtham, Keating, and Spencer 1987).

Next, rerun the same fiscal expansion under a target zone regime, where the zones are to be defended by monetary policy. In such a scenario, the appreciation of the currency induced by the fiscal action will prompt a loosening of monetary policy to keep the rate from breaching the zone. Here, coordination around a single indicator, namely, the exchange rate, will have exacerbated-not corrected-the basic cause of the problems. ${ }^{28}$ The single indicator would have sent the wrong signal for policy adjustment.

In contrast, a multi-indicator approach to coordination-assuming that the list of indicators included monetary and fiscal policy variables - would not be susceptible to this weak or false signal problem. This is because such an approach goes directly to the basic stance of fiscal and monetary policies, rather than passing through the medium of the exchange rate. If, for example, the impetus for coordination was a misalignment of exchange rates, and if the root cause of the misalignment was an inappropriate stance and/or mix of monetary and fiscal policies, the multi-indicator approach would be appealing. 
But all is not a bed of roses here either. While all effective approaches to coordination require a consistency of policy instruments and targets within and across countries, this requirement of consistency or compatibility can take an added prominence when authorities make public a set of targets and intended courses for policy instruments.

Two aspects merit explicit mention. One is that exchange rate targets-or even concerted views on the existing pattern of exchange rates-must be consistent with the announced course of monetary and fiscal policies. Without that consistency, attempts to provide the market with an anchor for mediumterm exchange rate expectations are likely to prove fruitless.

The second point is that the credibility of multiple policy targets also hinges on the constraints on policy instruments. Two such constraints are the striking inflexibility of fiscal policy in almost all industrial countries (Tanzi 1988), and the limited ability of sterilized exchange market intervention to affect the level of the exchange rate over the medium-term, unless of course it provides a signal about the future course of policies (Mussa 1981; Jurgensen 1983). A relevant concern is that limitations on other policy instruments may wind up with monetary policy being asked to carry too heavy a burden - with primary responsibility for maintaining internal and external balance. In such a case, any contribution that a multi-indicator approach to coordination could make to enhancing the predictability of policies would also be diminished. This is so because a shock to the system-such as the October 1987 global stock market crash-might raise in the minds of market participants the question of whether monetary policy would serve its internal or external master.

Some of the broad issues dealing with mechanisms of coordination can be more concretely illustrated by reviewing several of the salient features of the use of indicators in the ongoing G-7 coordination process.

Indicators assist the policy coordination process in at least four ways. First, they are used to help identify likely inconsistencies between prospective policies and targets, as well as among targets themselves - both within and across countries. Second, they serve as a monitoring device to ascertain whether short-term policy actions and performance are "on track" with respect to earlier announced medium-term projections and objectives. Third, indicators are employed to help gauge the international implications of domestic policies and performance for variables such as external payments positions and exchange rates, and to help reach judgments about whether such implications are desirable and sustainable. Finally, indicators serve as a common data base and terms of reference for assessing the current economic situation and policy options; in their absence, policy discussions could become bogged down by disagreements on "what is" - to say nothing about what should be.

The idea of using indicators in multilateral surveillance predates the recent strengthening of coordination. In 1972-74, a working group of the Committee of Twenty on Reform of the International Monetary System examined how 
objective indicators might be used to allocate the burden of adjustment to international payments disequilibriums (IMF 1974). That work was abandoned with the move to floating exchange rates because it was thought-erroneously, with the benefit of hindsight - that problems of balance of payments adjustment would henceforth be less serious (Crockett 1987). In the wake of the Plaza Agreement, new life was breathed into the use of indicators at the April 1986 meeting of the Interim Committee. Its communiqué suggested, inter alia, that "An approach worth exploring further was the formulation of a set of objective indicators related to policy actions and economic performance, having regard to a medium-term framework" (IMF 1986). The Tokyo Economic Summit of May 1986 gave further support to the use of indicators in the G-7 coordination process. The Tokyo Economic Declaration also specified that the list of indicators should include: GNP and domestic demand growth, inflation, unemployment, trade and current account positions, monetary conditions, fiscal balances, exchange rates, and international reserves.

In terms of our earlier discussion, the application of indicators within the G-7 coordination exercise is better characterized as a discretionary, multipleindicator approach than as a rule-based, single-indicator one. As hinted at earlier, these two characteristics of the present approach are related: so long as countries have multiple objectives and weight them differently, a multipleindicator approach may be the only politically feasible one; and once a multiple-indicator approach is adopted, the more likely it is to be discretionary than rule-based. Indeed, there has been widespread agreement in official circles that indicators should be used as an analytical framework for coordination discussions rather than as automatic triggers for policy actions.

Mention should also be made of two recent initiatives in the use of indicators. As proposed at the Venice Economic Summit in 1987 and incorporated in subsequent coordination meetings, aggregate indicators for the G-7 as a whole have been added to the list of individual-country indicators. Aggregate indicators for the group may include such variables as the growth rates of real GNP and of domestic demand, the current account position, and the real exchange rate. Aggregate indicators are intended to fulfill two purposes: to capture the effects of policies of G-7 countries on countries not directly sitting at the table, and to gauge whether the overall stance of policies in major countries is biased toward expansion or contraction. On the first point, alternative policy packages among the larger industrial countries may have quite different implications for developing countries, depending on how they affect such variables as world interest rates, world economic activity, and the volume of world trade. Aggregate indicators are a shorthand mechanism for inferring the magnitude of these linkages between the industrial and developing countries. On the second point, focus on individual-country indicatorsfor instance, on real exchange rates - does not give a reading on whether aggregate policy is too inflationary or deflationary. In fact, it was this very concern that coordinated policies might lead to either global inflation or global 
contraction which prompted former U.S. Treasury Secretary Baker and U.K. Chancellor Lawson, at the 1987 Fund-Bank Annual Meeting, to propose a commodity-price basket indicator. This aggregate indicator is intended to serve as a potential "early warning signal" of emerging inflationary or deflationary pressures. The basket includes prices of primary commodities that are traded on world markets and are widely consumed. Issues arise in the construction of the basket about the treatment of oil, the relative weights to be applied to the component commodities, and the currency denomination of the index. Preliminary econometric work suggests that a commodity-price indicator does have some value as a leading indicator of movements in $\mathrm{G}-7$ consumer prices (Boughton and Branson 1988).

\subsection{The Effects of Coordination}

Identifying key issues related to the rationale and mechanisms for economic policy coordination is one thing; attempting to infer its effects is quite another. The latter is obviously an empirical question that requires for analysis some type of quantitative economic model.

Efforts to gauge the effects of international economic policy coordination or of alternative international monetary arrangements fall into two categories. One strand of the literature compares the value of a welfare function where each country maximizes welfare independently with that where the countries maximize a joint welfare function. Two controversial findings are that the gains from coordination are likely to be "small" for the largest countries and that the gains can even be negative if countries coordinate using the "wrong" model of the world economy. ${ }^{29}$

These findings should not be used as an indictment of coordination-for at least five reasons. First, a comparison of optimal uncoordinated with optimal coordinated policies may not be generalizable to the more relevant comparison of suboptimal uncoordinated with suboptimal coordinated policies. In particular, the link between pressures for protectionism on the one hand, and recession and exchange rates on the other, could result in quite a different counterfactual (i.e., what would happen in the absence of coordination) from that assumed in these studies. ${ }^{30}$ To take a specific example, in evaluating the effects of the Plaza Agreement of September 1985, one should ask how protectionist pressures in the U.S. Congress might have evolved in its absence. Second, some of the gains from coordination may be unobservable (unwritten pledges to alter policies in the future), or difficult to separate from less ambitious forms of cooperation (exchange of information across countries), or may extend beyond the realm of macroeconomic policy (joint measures to combat terrorism, to harmonize international fare schedules for air travel, and so on). Third, a judgment that gains from coordination are small presupposes some standard of comparison. Would the gains from international coordination be small relative to the gains from coordination of policies across different 
economic agencies within a national government? ${ }^{31}$ Fourth, empirical estimates of gains from coordination have typically compared policies that do not exploit the incentive governments have to adhere to agreements in order to enhance their reputation for consistency. Currie, Levine, and Vidalis (1987) argue, in contrast, that comparison of "reputational" policies shows large gains. Fifth, the danger that coordination may reduce welfare because policymakers use the wrong model(s) is greatest if they ignore model uncertainty. If, however, policymakers recognize that they do not know the true model and take this uncertainty into account, policy may be set in a more cautious fashion, with positive effects on the gains from coordination (Ghosh and Masson 1988).

The second strain of the empirical literature attempts to quantify the effects of specific policy proposals (such as the introduction of target zones) by comparing them either with a baseline that describes the current policy stance, or with historical values for the macroeconomic variables of interest. This typically involves the simulation of a global econometric model. To date, most attention has been paid to rule-based proposals for policy coordination that focus on real effective exchange rates. Two examples of such studies are Edison, Miller, and Williamson (1987) and Currie and Wren-Lewis (1987). They compare simulated outcomes of cooperative policy rules to recent historical experience. Both of these studies, however, are open to the classic Lucas (1976) critique that, due to the endogeneity of expectations of economic agents, as well as other endogenous responses to the policy regime, estimates of "structural parameters" will differ under different policy regimes; in these studies, expectations are formed in a mechanistic fashion-independent of the policy regime.

In this paper, we present some preliminary rule-based simulations derived from a global macroeconomic model developed in the research department of the IMF and called MULTIMOD. Two sets of simulations results are reported. The first set might be called historical simulations. Here, we address two questions: (a) whether a smoother path of monetary and fiscal policies would have produced a smoother path for real exchange rates, real output, and inflation than that observed historically; and (b) what the variability of policy instruments would be under a simple or extended "target zone" scheme where the real effective exchange rate is treated as an intermediate target (Williamson 1985 [1983]; Williamson and Miller 1987). In these historical simulations, the "effects" of coordination are generated by comparing the counterfactual simulations to a baseline simulation where MULTIMOD is constrained to replicate the historical data over $1974-87$ by including the appropriate residuals in each equation. These same residuals are also used in the counterfactual simulations, each of which postulates that policy would have been different in some way from its historical stance. Our second set of simulations-for convenience, labeled single-shock simulations-disregard the historical record and focus instead on hypothetical 
individual shocks to particular behavioral relationships in the model. More specifically, we consider shocks to the demand for money, to aggregate supply, to aggregate demand, to export demand, and to portfolio preferences. Responses to these shocks are then examined under alternative policy rules. In addition to the coordinated rules of simple and extended target zones, we also study monetary targeting and nominal GNP targeting. In short, the objective is to see if, when, and how certain rules are likely to perform better than others.

It could be objected that the rules we consider do not constitute "coordination" in the sense of joint utility maximization, which is the focus of the first strand of literature discussed above. While true, there is certainly an element of coordination in such rules, in the usual meaning of the term (see Frankel, ch. 3 in this volume). In particular, target zones would have to involve agreement concerning a consistent set of targets; because of the $N-1$ problem, targets for real effective exchange rates cannot be chosen independently.

By virtue of using MULTIMOD for the simulations, our approach differs from most earlier work in two important respects. One is that expectations are forward-looking and reflect the stance of policy. This permits expectations to differ across different policy regimes. ${ }^{32}$ For instance, if it is known that the monetary authorities will resist movements away from an "equilibrium" level for the exchange rate, then this will condition the value expected for the exchange rate in the future. In this sense, the results are less subject to the Lucas critique than most of previous work. ${ }^{33}$ In a related vein, the model attributes complete credibility to the government's policy stance and assumes that the private sector forms its expectations in a fashion that turns out to be correct ex post. Thus, it gives a potentially powerful influence to changes in present and future policies. Second, although this paper concentrates on the larger industrial countries, MULTIMOD contains a fully specified developing country block.

Before proceeding to a capsule summary of MULTIMOD and to the simulations themselves, it is worth emphasizing a caveat. We are in a still early stage of applying MULTIMOD to policy coordination issues. The results should, therefore, be considered tentative, preliminary, and relevant only to a few rule-based proposals. Much more will need to be learned over time about which aspects of the simulations are quite model specific, about the sensitivity of the conclusions to particular parameter values, and about the effects of alternative coordination proposals-including those that rely on a judgmental or discretionary application of policies. ${ }^{34}$

MULTIMOD is documented fully elsewhere (Masson and others 1988), and we will therefore limit ourselves here to describing its main features. The model contains separate submodels for the three largest industrial countriesthat is, for the United States, Japan, and the Federal Republic of Germany-for the remaining four G-7 countries as a group (France, the United Kingdom, Italy, and Canada), and for the remaining smaller industrial countries as a 
group. Developing countries (excluding the high-income oil exporters) are modeled as one region, but with some industrial disaggregation. Each of the country or regional submodels has equations explaining the components of aggregate demand as well as the supply of the various goods produced. The submodels are linked through trade and financial flows. The parameters of the behavioral equations are in most part estimated using annual data available since the early 1960s.

In the case of industrial countries, financial markets are assumed to exhibit both perfect capital mobility and perfect substitutability between assets denominated in different currencies. ${ }^{35}$ Consequently, arbitrage conditions link the returns on long- and short-term bonds and on domestic and foreign bonds. Moreover, as suggested earlier, expectations are assumed to be forwardlooking and to be consistent with the model's solution in future periods. Thus interest parity holds both ex ante and ex post in model simulations where future variables are correctly anticipated-that is, where there are no "surprises" after the first simulation period, ${ }^{36}$ As a result, the change in the exchange rate between two currencies from one period to the next is determined by their interest differential prevailing in the first period.

Similarly, expected long-term bond rates and rates of inflation are also consistent with the model's solutions for future periods in the absence of further shocks. The rate of inflation-unlike prices in financial markets-is not assumed perfectly flexible. Instead, rigidities in wage and product markets make for persistent effects on output as a result of purely monetary shocks; only in the medium to long run will full employment result. ${ }^{37}$ Thus, both monetary and fiscal policies of the industrial countries have significant and persistent effects on real variables, both in the country undertaking the policy change and in other countries.

In order to provide some feel for the properties of MULTIMOD, table 1.1 shows the effects of monetary and fiscal policies in each of the three major countries on itself, on the other three major countries, and on the remaining G-7 countries. ${ }^{38}$ These policy changes are assumed to be unanticipated at the time of initiation. Two comments are in order about the results. First, and not surprisingly, policy actions taken by the United States have much larger spillover effects than those undertaken in Japan or in the Federal Republic of Germany. This reflects the large size of the U.S. economy and the fact that, while it is a relatively closed economy to imports, a relatively large share of its imports come from other G-7 countries. Japan is only roughly half as large (in terms of GNP) and obtains more of its imports from outside the G-7 sources. Germany is the most open but is smaller than Japan; the spillovers of its actions primarily affect other European countries. Second, while both monetary and fiscal policies have strong effects on domestic real output over the medium term, fiscal policy has a much larger own-effect on the current account than does monetary policy. ${ }^{39}$ This is because the output and relativeprice effects go in the same direction for a fiscal policy change, whereas they 


\begin{tabular}{|c|c|c|c|c|c|c|c|c|c|c|c|c|}
\hline \multirow[b]{2}{*}{$\begin{array}{l}\text { Country Taking } \\
\text { Action }\end{array}$} & \multicolumn{4}{|c|}{ Real GDPa } & \multicolumn{4}{|c|}{ Current balance $^{b}$} & \multicolumn{4}{|c|}{ Real effective exchange rate ${ }^{a}$} \\
\hline & $\begin{array}{l}\text { United } \\
\text { States }\end{array}$ & Japan & Germany & $\begin{array}{l}\text { Other G-7 } \\
\text { Countries }\end{array}$ & $\begin{array}{l}\text { United } \\
\text { States }\end{array}$ & Japan & Germany & $\begin{array}{l}\text { Other G-7 } \\
\text { Countries }\end{array}$ & $\begin{array}{l}\text { United } \\
\text { States }\end{array}$ & Japan & Germany & $\begin{array}{r}\text { Other G-7 } \\
\text { Countries }\end{array}$ \\
\hline & \multicolumn{12}{|c|}{ Government Spending Increase of $1 \%$ of GNP in $1988^{c}$} \\
\hline \multirow{2}{*}{ United States } & 1.2 & 0.5 & -0.1 & 0.2 & -13 & 3 & -1 & 3 & 1.5 & -0.3 & -0.1 & -0.5 \\
\hline & 0.6 & 0.6 & 0.1 & 0.6 & -18 & 6 & - & 7 & 1.8 & -0.2 & -0.4 & -0.6 \\
\hline \multirow[t]{2}{*}{ Japan } & - & 1.5 & -0.1 & 0.1 & 1 & -5 & - & 2 & 0.1 & 0.5 & 0.1 & -0.3 \\
\hline & 0.1 & 0.6 & - & 0.3 & 1 & -8 & 1 & 4 & -0.1 & 0.9 & - & -0.4 \\
\hline \multirow[t]{3}{*}{ Germany } & 0.1 & 0.1 & 0.8 & 0.2 & 1 & 1 & -6 & 2 & -0.3 & -0.2 & 0.7 & -0.2 \\
\hline & 0.1 & 0.2 & 0.3 & 0.2 & - & 2 & -5 & 3 & -0.4 & -0.3 & 0.9 & -0.2 \\
\hline & \multicolumn{12}{|c|}{ Increase in Money Supply Target by $5 \%$ Relative to Baseline } \\
\hline \multirow[t]{2}{*}{ United States } & 1.2 & -0.5 & -0.3 & -0.1 & 6 & 5 & 5 & - & -3.8 & 0.6 & 1.4 & 0.6 \\
\hline & 0.8 & -0.2 & -0.1 & -0.1 & 6 & 5 & 6 & -1 & -2.1 & 0.3 & 1.0 & 0.3 \\
\hline \multirow[t]{2}{*}{ Japan } & -0.1 & 1.1 & - & - & -1 & 3 & - & -1 & 0.4 & -2.2 & 0.3 & 0.6 \\
\hline & -0.1 & 1.0 & -0.1 & -0.3 & -1 & 6 & -1 & -4 & 0.3 & -1.2 & - & 0.4 \\
\hline \multirow[t]{2}{*}{ Germany } & -0.1 & - & 2.1 & - & -1 & - & - & 1 & 1.2 & 0.8 & -3.5 & 1.0 \\
\hline & - & -0.1 & 1.1 & -0.2 & - & -1 & -1 & -1 & 0.7 & 0.5 & -1.8 & 0.5 \\
\hline
\end{tabular}

Note: First and second rows for each entry correspond to first and third year domestic and foreign effects.

apercentage deviation from baseline.

beviation from baseline, billions of dollars.

'Temporary; each successive year is $70 \%$ of previous year's. 
offset each other in the case of monetary policy. A fiscal expansion, for example, induces an appreciation of the real exchange rate and an increase in domestic demand-both of which lead to a fall in net exports ${ }^{40}$ In contrast, a monetary expansion yields a depreciation of the real exchange rate-which promotes net exports - and an increase in domestic demand-which penalizes them; because the relative-price effect dominates-at least in the case of the United States and Japan-the result is a small improvement in the current account.

\subsubsection{Historical Simulations}

One rather minimalist interpretation of coordination is that large countries should use their monetary and fiscal policies in a largely independent decentralized way but should avoid sharp changes in policy stance that would, in turn, generate sharp changes in real exchange rates. Such a concession to internalizing externalities would not affect the ultimate size of the stock adjustment of actual to desired policies but would constrain the speed of adjustment-much in the same spirit that speed limits in boat marinas discourage large boats from producing wakes that would topple smaller boats. One exponent of "smoothing"' guidelines is Corden $(1986,431)$, who states: ${ }^{41}$

If we accept that the spillover effects of a foreign fiscal policy change can be defined as the adverse effects of the destabilization of the real exchange rate, two implications follow.

The most important implication is that each country benefits the other by maintaining relatively stable policies, meaning policies which will minimize real exchange-rate changes in either direction. Coordination consists essentially of a reciprocal agreement to modify policies that generate real exchange-rate instability.

Figures 1.1 to 1.3 summarize developments for some indicators of policy stance since the first full year of generalized floating (1974), while figure 1.4 gives a measure of real effective exchange rates for the G-7 countries. ${ }^{42}$ There are well-known difficulties in getting good policy indicators, including the problem that each of the series-money growth, the share of government purchases on goods and services in GNP, and the ratio of tax receipts less noninterest transfer payments to net national product and interest receipts-are all endogenous to some extent. It should also be emphasized that this historical period contains several different policy regimes, ranging from targeting of monetary aggregates over much of the earlier part of the period, to the strengthening of international economic policy coordination since the Plaza Agreement of September 1985.

Nevertheless, some useful stylized facts emerge from an examination of historical data. First, money growth rates are quite volatile and appear to be positively correlated across economies. Second, taxes net of transfers seem to exhibit more variation than government spending; evidence of fiscal stimulus 


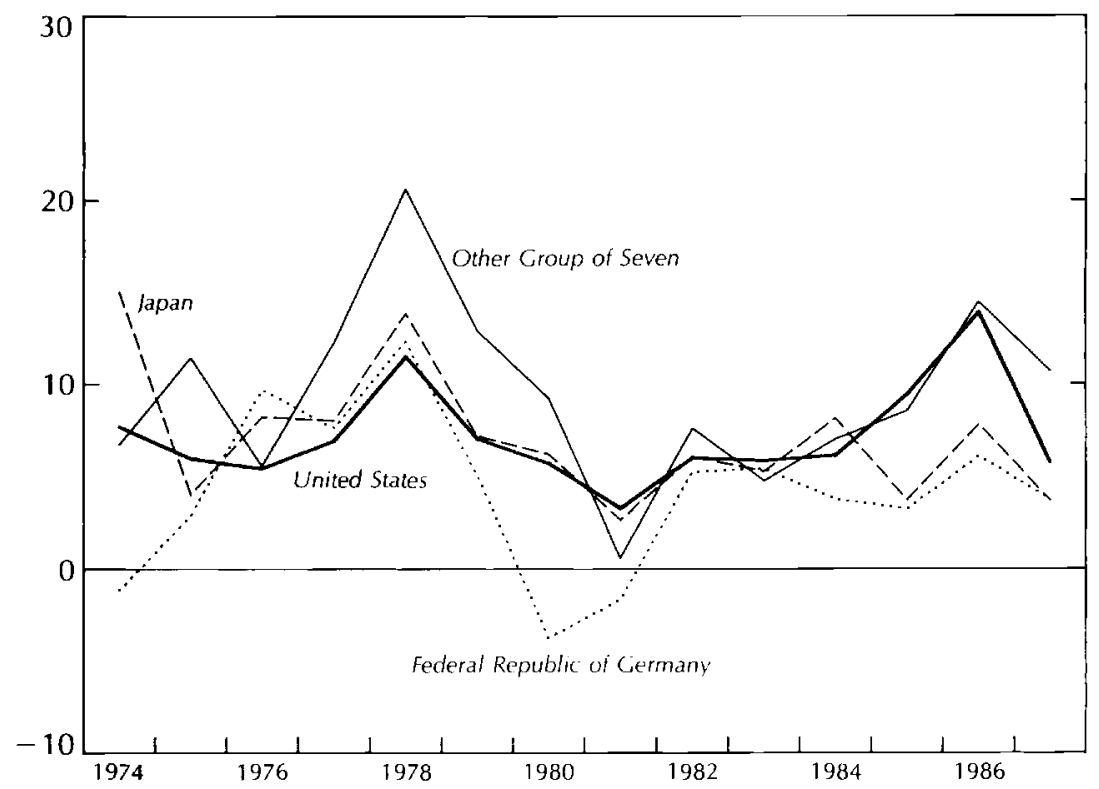

Fig. 1.1 Money growth rates: actual values (percent change)

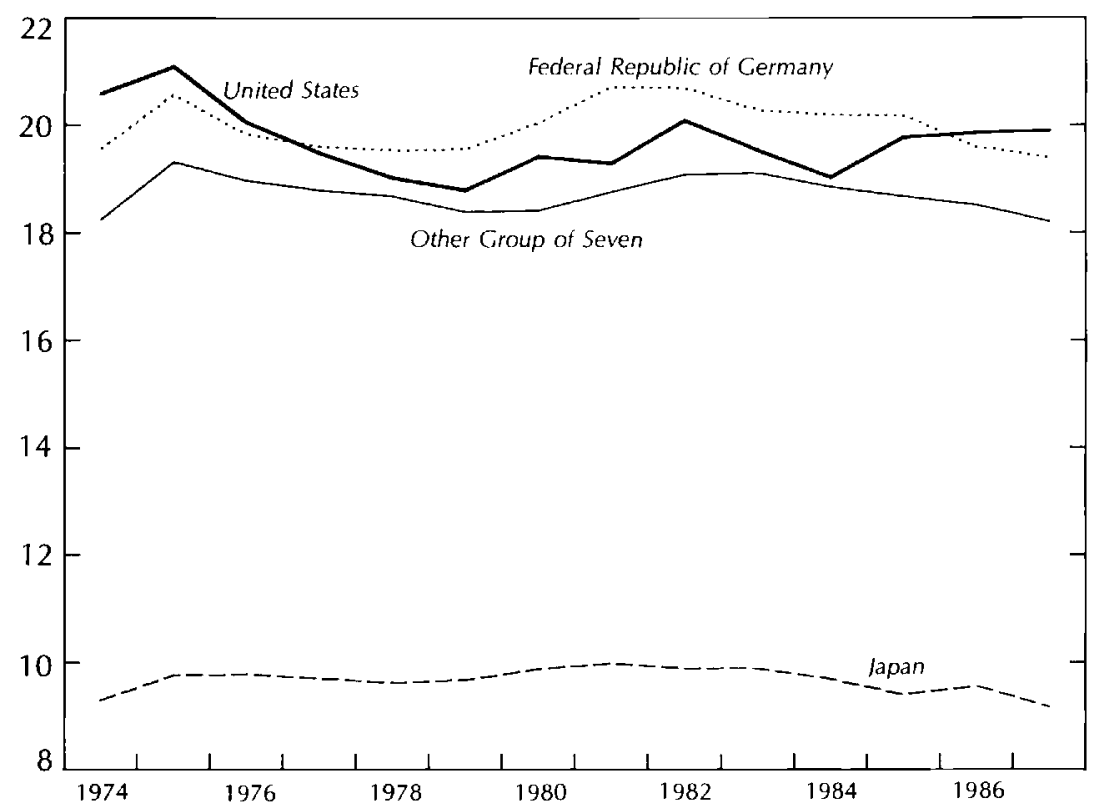

Fig. 1.2 Government spending share: actual values (percent of GNP) 


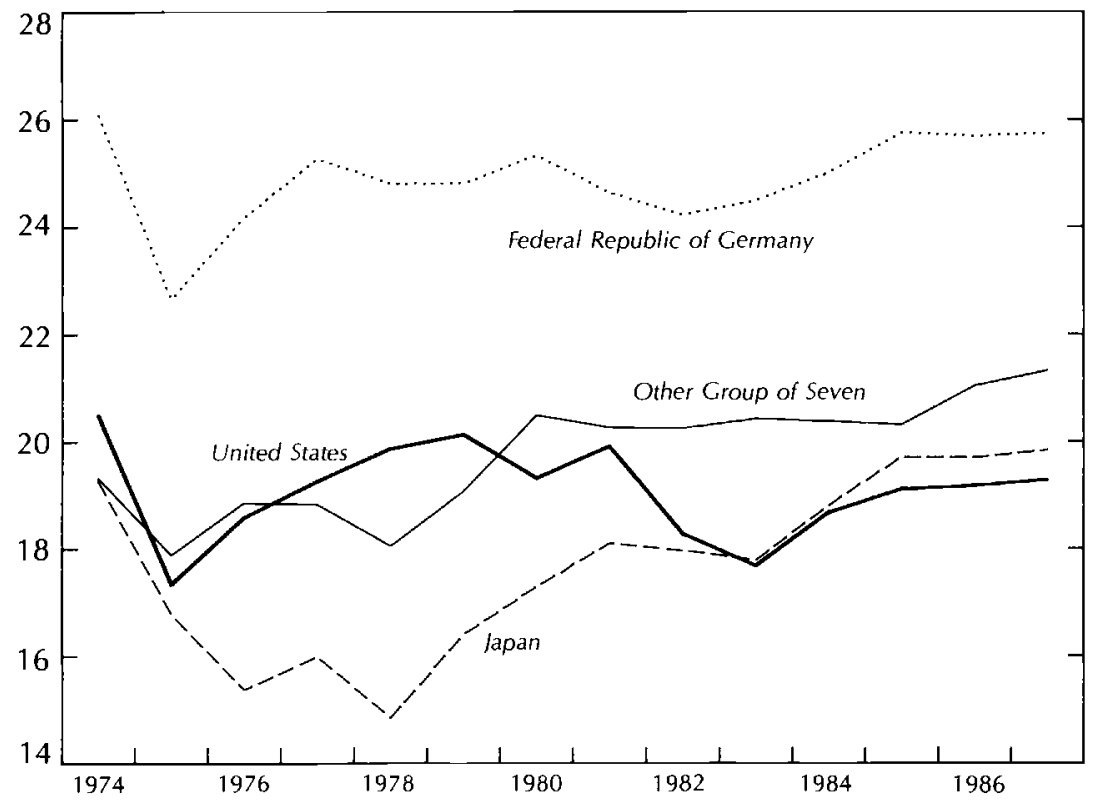

Fig. 1.3 Tax rates: actual values (percent)

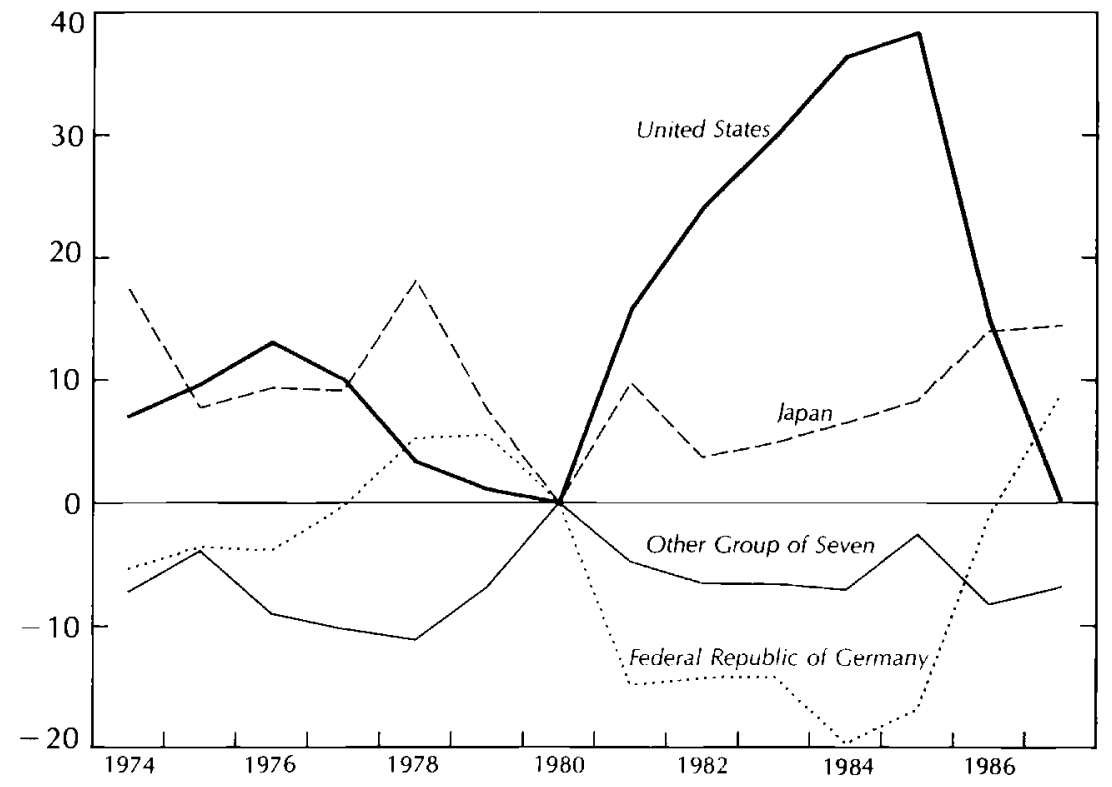

Fig. 1.4 Real effective exchange rates: actual values (percentage deviation from 1980 value) 
in the United States in 1983 is clear. Finally, real exchange rates exhibit large fluctuations, especially for the United States.

To estimate the effects of "smoother" policies, each of the variables in figures 1.1 to 1.3 was replaced by its five-year moving average. Those values then were input as exogenous variables into MULTIMOD, and the values of endogenous variables were calculated.

Table 1.2 presents the mean and standard deviation of several macroeconomic indicators, comparing their historical values with those resulting from a simulation of smoother policies. Interestingly enough, smoothing of policy variables is nowhere near sufficient to produce smooth values for major macroeconomic variables. On the contrary, such a simple smoothing rule tends to accentuate some of the fluctuations in the historical data. For example, though the average growth of real gross domestic product is about the same as in the historical data, its standard deviation is higher in the policy smoothing simulation. Real effective exchange rates are somewhat less variable with smoothing, but real short-term interest rates are considerably more variable.

Table 1.2

MULTIMOD Simulations: Comparisons of Historical Policy Stance with Values of Endogenous Variables when Money Growth, Tax Rates, and the Stance of Government Spending in GDP are Smoothed, 1974-1987

\begin{tabular}{|c|c|c|c|c|}
\hline \multirow[b]{2}{*}{ Variable } & \multicolumn{2}{|c|}{ Mean Values } & \multicolumn{2}{|c|}{ Standard Deviations } \\
\hline & $\begin{array}{l}\text { Historical } \\
\text { Values }\end{array}$ & $\begin{array}{l}\text { Simulated } \\
\text { Values under } \\
\text { Smoothing }\end{array}$ & $\begin{array}{l}\text { Historical } \\
\text { Values }\end{array}$ & $\begin{array}{l}\text { Simulated } \\
\text { Values under } \\
\text { Smoothing }\end{array}$ \\
\hline \multicolumn{5}{|l|}{ Growth rate of real GDP } \\
\hline United States & 2.5 & 2.6 & 2.8 & 4.6 \\
\hline Japan & 3.7 & 3.8 & 1.8 & 2.9 \\
\hline Germany & 1.9 & 2.0 & 1.9 & 3.6 \\
\hline Other Group of Seven & 2.2 & 2.4 & 1.4 & 3.0 \\
\hline \multicolumn{5}{|l|}{ Rate of inflation } \\
\hline United States & 6.5 & 7.4 & 3.0 & 3.0 \\
\hline Japan & 5.0 & 6.5 & 6.0 & 5.9 \\
\hline Germany & 3.9 & 4.5 & 2.1 & 1.9 \\
\hline Other Group of Seven & 10.2 & 11.4 & 5.4 & 6.1 \\
\hline \multicolumn{5}{|c|}{$\begin{array}{l}\text { Real effective exchange rate } \\
\quad(1980=0)\end{array}$} \\
\hline United States & 14.6 & 16.3 & 12.9 & 11.7 \\
\hline Japan & 9.4 & 9.3 & 5.2 & 5.1 \\
\hline Germany & -5.4 & -5.1 & 9.1 & 8.9 \\
\hline Other Group of Seven & -6.6 & -8.6 & 3.0 & 3.1 \\
\hline \multicolumn{5}{|l|}{ Real short-term interest rate } \\
\hline United States & 2.1 & 2.5 & 3.6 & 4.4 \\
\hline Japan & 2.7 & 2.5 & 3.5 & 4.6 \\
\hline Germany & 2.9 & 2.7 & 2.4 & 3.1 \\
\hline Other Group of Seven & 2.3 & 2.4 & 5.7 & 6.8 \\
\hline
\end{tabular}


This simulation illustrates that smoothing policy instruments may lead to less, not more, smoothness in target variables. Other variables exogenous to the model are also a source of variation in output and exchange rates. The model simulation suggests that the random shocks over the historical period, including changes in nonpolicy variables such as oil production, have had a greater influence in producing swings in exchange rates and in economic activity than economic policy variables. The role of policy has been to accommodate partially those shocks. For instance, money growth rates were increased initially after the first and second oil price shocks, but a permanent increase was resisted. The basic point is that the variability of policy instruments has to a large degree been a response to shocks, rather than an exogenous source of instability; ${ }^{43}$ put in other words, the historical period already contains considerable smoothing - albeit of a discretionary rather than rule-based variety - and therefore attempts to impose additional smoothing on top of it do not produce salutary effects.

Note also that real effective exchange rates take on values in this simulation that are very similar to the historical data, though they are somewhat less volatile when policy is smoothed. There seems to be little support here for the notion that exchange rate stability can be achieved solely through the application of simple mechanical smoothing rules. Recall, however, that the smoothing simulation has only considered a change in the path of policy variables-leaving their end points unchanged--rather than a permanent change in those variables. A permanent increase in the rate of money growth or in the shares of taxes or government spending in output might have more powerful effects.

A more activist approach to the coordination of economic policies would go beyond smoothing. One such approach would be to postulate that monetary authorities resist movements of an intermediate variable-in particular the real effective exchange rate-from their long-run equilibrium levels. A system of target zones for exchange rates has been proposed by Williamson (1985 [1983]) and extended by Williamson and Miller (1987). The original proposal calculated "fundamental equilibrium exchange rates" and advocated the use of monetary policies to resist movements away from those rates. As explained by Williamson:

The basic focus of exchange rate management should be on estimating an appropriate value for the exchange rate and seeking to limit deviations from that value beyond a reasonable range. $(1985[1983,47])$

While other techniques, like sterilized intervention, may be able to give limited assistance, a serious commitment to exchange rate management leaves no realistic alternative to a willingness to direct monetary policy at least in part toward an exchange rate target. (56)

More recently, Williamson and Miller $(1987,7)$ supplement the prescription that monetary policies be used to target real effective exchange rates with the assignment of fiscal policies to targets for the growth in domestic demand for the G-7 countries: "The basic argument is that a nominal income target fulfills 
the same function as a money supply rule, providing a "nominal anchor" to prevent inflation from taking off and a guide to expectations, while avoiding the shocks to demand that come from variations in velocity." In addition, the proposal, or "blueprint," specifies that "the average level of world (real) short-term interest rates should be revised up (down) if aggregated growth of nominal income is threatening to exceed (fall short of) the sum of the target growth of nominal demand for the participating countries."

Earlier simulation studies of target zones have been undertaken by Williamson and Miller (1987, App. C), based on Edison, Miller, and Williamson (1987). Those studies employed the Federal Reserve Board's multicountry model (MCM), which is characterized by adaptive expectations. As emphasized earlier, MULTIMOD uses model-consistent forward-looking expectationsa difference that should, in our view, produce more firmly grounded answers.

Two simulations were performed-one for the original target zone proposal (labeled "target zones"), and one for target zones augmented by a rule for fiscal policy (labeled "blueprint"). The attempt was made to stay close to the spirit of the original proposals while still making a few minor modifications.

Much of the action in a target-zone scheme centers around the monetary reaction function since it is monetary policy that is typically assigned to the exchange rate. In the standard version of MULTIMOD, the reaction function for short-term interest rates involves resisting movements away from an exogenous target for base money. The demand for base money, in turn, is assumed to depend on real GNP and on its deflator with elasticities close to unity. When the effects of target zones are simulated, this term is retained but with a much lower weight than normal. ${ }^{44}$ The "target-zone" element in the reaction function is represented by the assumption that the short-term interest rate deviates from the baseline depending on the cube of the deviation of the real effective exchange rate from its target value (Edison, Miller, and Williamson 1987, 97). Thus, the monetary policy rule used in both the target-zone and blueprint simulations takes the following algebraic form:

$$
R=R^{b}+[(c-\bar{c}) / n]^{3}+a[\bar{m}-m],
$$

where, as in Edison and others (1987), $R$ is the short-term rate, $R^{b}$ is its baseline value, $c$ is the log of the real effective exchange rate, $\bar{c}$ its target value, and $n$ is half the width of the target zone, (namely, 10 percent); $\bar{m}$ is the target for the (log of the) monetary base, $m$ the long-run demand for the monetary base with baseline interest rates but simulated output and prices, and $a$ is a negative constant. ${ }^{45}$

Targets for the real effective rate were taken from Williamson (1985 [1983]) ${ }^{46}$ As in Edison, Miller, and Williamson (1987), an adjustment to the level of the target real effective rate is made to keep it compatible with the definition used in the model, but the constraint is imposed that the translated 
target exchange rate variable follow the same path as in Williamson (1985 [1983]). ${ }^{47}$

As mentioned earlier, the "blueprint" proposes that fiscal policy follow a rule targeted on nominal domestic demand growth. As such, the equations in MULTIMOD for real government spending on goods and services had to be endogenized along such lines. The target paths for nominal domestic demand growth were taken from Williamson and Miller (1987) for the period 1980-87; outside that period, we used their formula to calculate targets.

The main results of interest are portrayed in figures 1.5 to 1.8 , where actual (historical) values are compared to simulated values for the target-zone proposal and for the blueprint proposal. The figures cover real effective exchange rates, real GNP growth rates, rates of inflation, and current account balances. Bands 10 percent each side of Williamson's (1985 [1983]) fundamental equilibrium exchange rates have been drawn on figure 1.5.

Several interesting - albeit tentative-conclusions emerge from the simulations.

First, there is surprisingly little success in limiting real exchange rate movements away from their targets, especially for the United States. ${ }^{48}$ This is apparent for both the more limited assignment of monetary policy to target exchange rates and the case where fiscal policy is made endogenous, though not specifically for exchange rate targeting. Also, the cost of resisting exchange rate movements in terms of greater variability of nominal interest rates appears to be quite high in the model. In 1985, the short-term rate in the United States is 370 basis points below its baseline value in the target-zone simulation, and 260 basis points above in Germany. An attempt to increase the feedback onto interest rates of real exchange rates produced explosive behavior in the model and negative nominal interest rates. Why is the movement in real effective exchange rates so small? In the model, this is the result of the long-run neutrality of real variables with respect to monetary policy, of the relatively small impact of interest rates on exchange rates when exchange rates are anchored by perfect foresight, and of the fact that monetary policy changes are anticipated in advance. A nominal depreciation resulting from anticipated monetary expansion leads quite soon to increases in import prices and domestic inflation, reducing the amount of real depreciation. Such a scenario has been discussed by Feldstein $(1988,7)$ in the following terms:

If the United States had agreed in 1983 to stop the dollar's rise, the easiest way would have been for the Federal Reserve to ease monetary policy. . . . The easier monetary policy would produce inflation and the inflation would cause the dollar's nominal value to decline. In the end, there would have been no change in the real exchange rate or the trade deficit but a higher price level and a high rate of inflation.

With perfect foresight of policy changes, the required movements in monetary policy may be quite large for even small, and transitory, real exchange rate changes. It can be seen from figure 1.5 that the dollar's real 

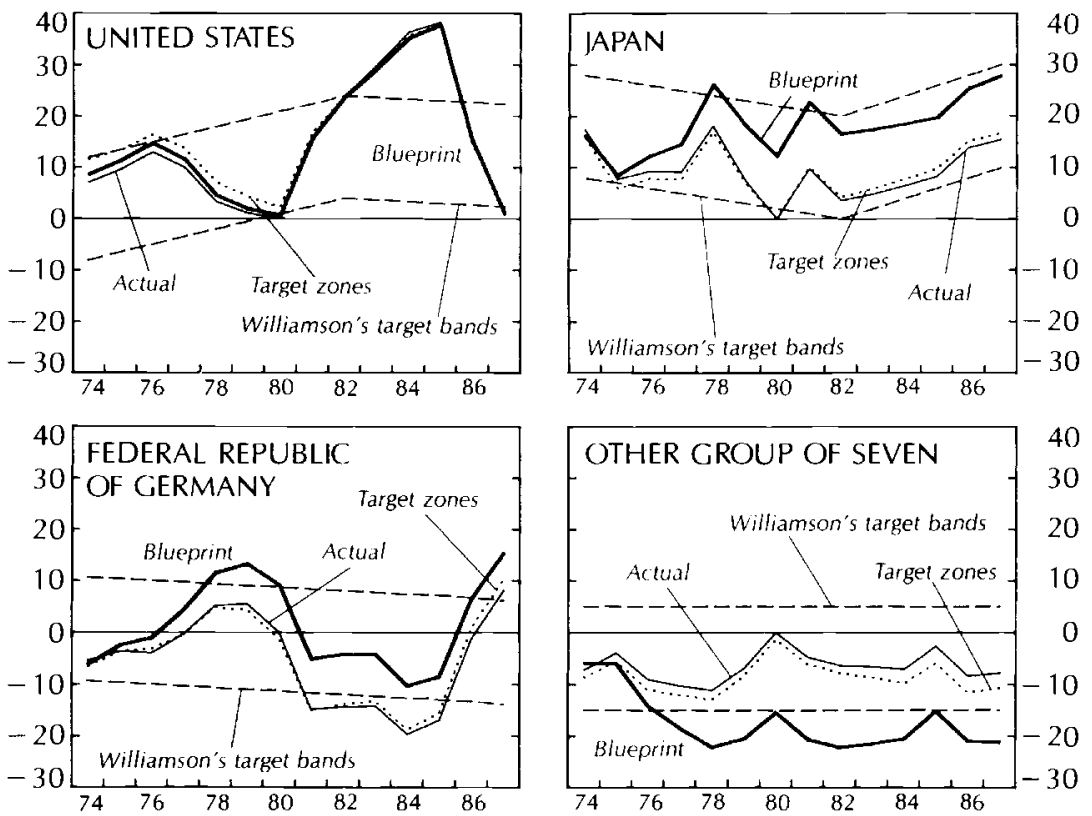

Fig. 1.5 Real effective exchange rates: actual and simulated values (percentage deviation from 1980 value)
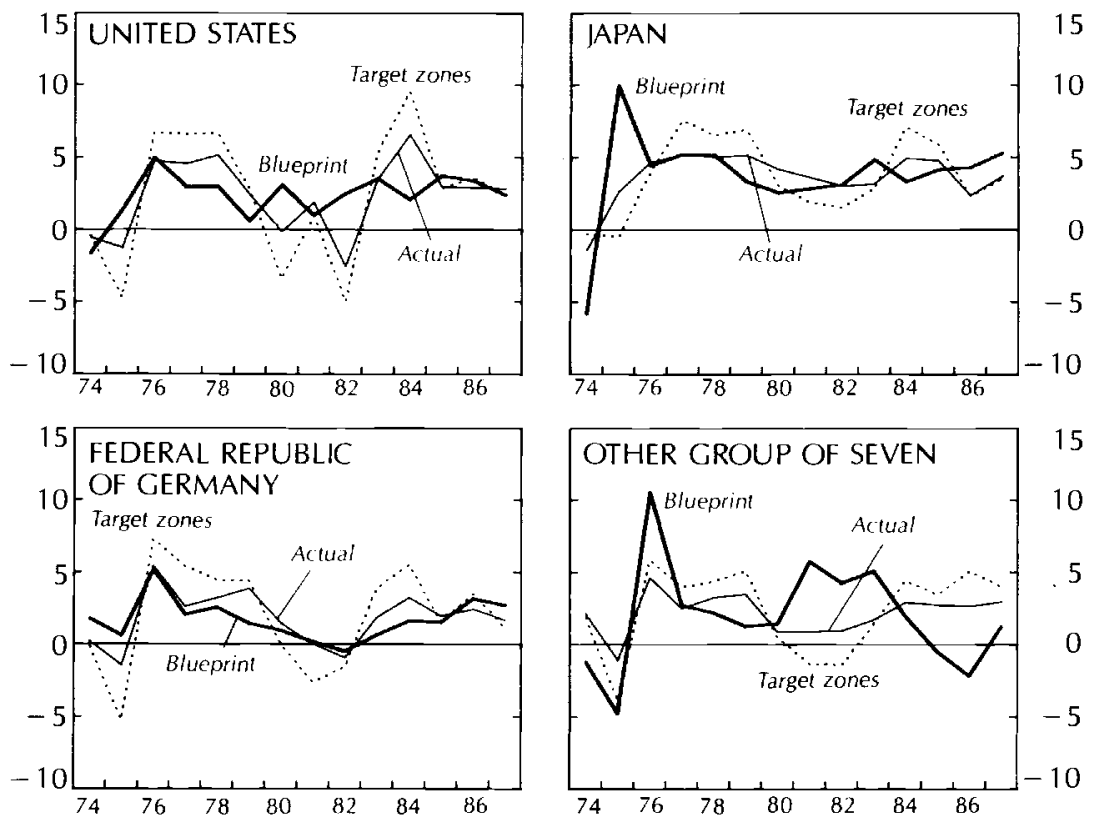

Fig. 1.6 Rate of growth of GNP: actual and simulated values (percent change) 

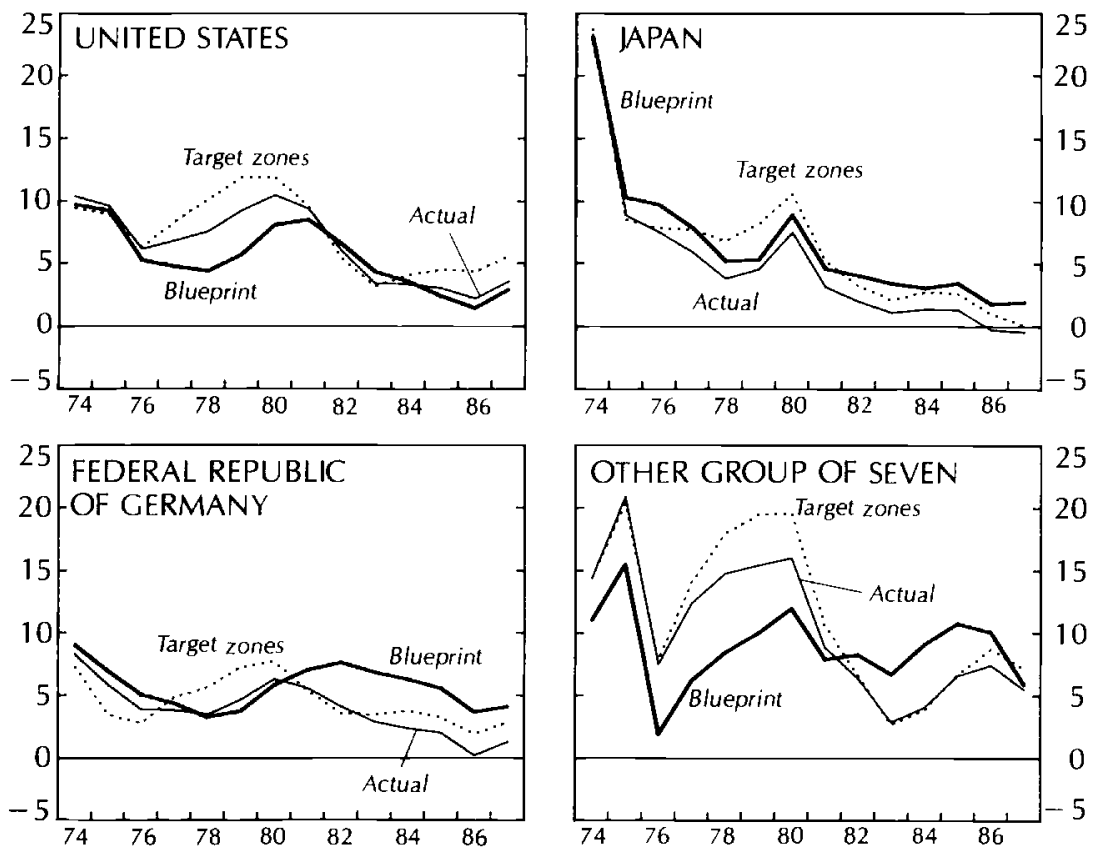

Fig. 1.7 Rate of inflation: actual and simulated values (percent)
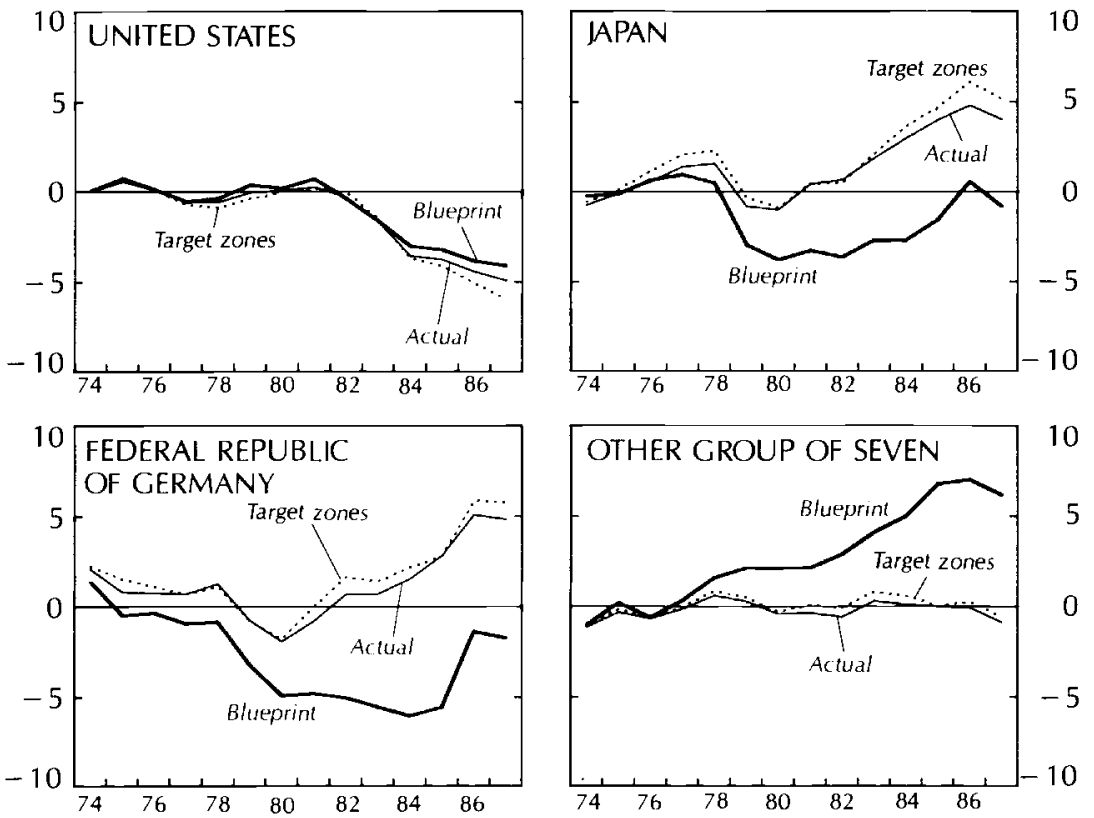

Fig. 1.8 Current account balance: actual and simulated values (percent of GNP) 
effective exchange rate is judged by Williamson and Miller (1987) to be undervalued in 1978-80, but overvalued from 1982 to 1985 . Thus, interest rates have to rise in the earlier period but fall in the latter (relative to baseline). With perfect foresight, the amount they must rise in the earlier period is amplified because it is known that they will be lower later. ${ }^{49}$ Note that monetary policy is effective in the model in the short run, provided that the money supply change is unanticipated. Table 1.1 indicates that an increase in the money supply of 5 percent causes a real effective depreciation in the first year ranging from 2 percent in the case of Germany to 4 percent in the United States; by the second year, the depreciation has been reduced to 1 to 2 percent. If anticipated beforehand, the extent of the depreciation is further reduced.

A second conclusion is that the use of monetary policy alone to maintain target zones-keeping the same stance of fiscal policy as in the baselineseems to exacerbate the inflationary pressures of the late 1970s and early 1980s, and to lead to more variable inflation rates; see figure 1.7. In this simulation, the United States eases monetary policy to prevent the dollar's appreciation in 1980-85; with perfect foresight of such a policy stance, inflation rises somewhat in the late 1970s in anticipation. Conversely, the dollar's undervaluation in 1987 (according to the calculated fundamental equilibrium exchange rate) requires a tightening of policy, which tends to lower inflation rates in the mid-1980s below baseline levels.

The substantial effects on real variables in the blueprint simulation appear to be the result mainly of the fiscal rule. In the blueprint simulation, GNP growth is smoothed considerably in the United States and the Federal Republic of Germany (see fig. 1.6). The recession of 1982 and the high growth of domestic demand in the United States in 1984 are both smoothed out; U.S. GNP growth in 1984 is only 2.7 percent, compared to 7.2 percent historically, while the United States no longer experiences a recession in 1982. Moderation of sharp GNP movements is however not so evident for Japan and the other G-7 countries. Indeed, the non-U.S. G-7 countries experience large output variations in 1975-76 in the blueprint simulations. This may be a result of a mechanical application (in the period up to 1980) of the Williamson-Miller formula for calculating nominal demand targets; if adjusted in an ad hoc fashion (as is done in Williamson and Miller 1987 for the second oil shock), a more reasonable path might result.

Third, current account imbalances are reduced for the major three countries in the blueprint simulation, in the sense of being closer to zero; see figure 1.8. Most of the effects again come as a result of the changes in fiscal stance. In particular, targets for domestic demand growth in Germany and Japan are consistently above the historical values, and this leads to a much more stimulative fiscal policy in these countries (see Williamson and Miller 1987, figs. 4 and 5). But again, there is a cost. General government fiscal deficits reach 10 percent of GNP in Germany and 8 percent in Japan in the early 1980s! 
By the same token, it is the fiscal stimulus-rather than the monetary policy change--that is the cause of the sizable appreciation of the yen and deutsche mark in the 1980s relative to baseline. Clearly, such large deficits would be neither desirable-nor tolerable politically. It is also noteworthy that the counterpart to the smaller current account surpluses in Germany and Japan is larger surpluses in the other G-7 countries, rather than a reduction of U.S. deficits. This occurs because a weighted average of domestic demand targets for France, the United Kingdom, Italy, and Canada in Williamson and Miller (1987) is consistently lower than actual demand over the period 1974-87.

\subsubsection{Single-Shock Simulations}

In our view, the results of the historical simulations are instructive. Still, it is not clear to what extent these results reflect either the specific shocks that were present in the 1974-87 historical episode or the assumption made that all exogenous variables-including the shocks-were known prior to their occurrence. Furthermore, because the historical data contain a great variety of shocks, interpretation of the simulation results is blurred. In what follows we do a set of simpler experiments with the model, where only one shock to a particular behavioral relationship is assumed to occur. The shock, which is assumed to have been unanticipated when it occurred, is an innovation that applies to a single period. Though temporary, the shock nevertheless has persistent effects because errors are serially correlated and because the structural equations of the model include lagged effects. Expectations are assumed to be formed in the model in a way that properly takes into account the subsequent dynamics; that is, once the shock has occurred, perfect foresight is assumed to prevail.

No more than the historical simulations, results from single shocks do not allow a complete evaluation of policy rules. Clearly, the relative variance of various shocks should influence the choice among policy rules (Poole 1970; Henderson 1979). The historical simulations that were discussed above do capture the relative importance of the different shocks, but only for one historical episode. More informative perhaps would be evaluation of policy rules under a series of drawings from the distribution describing the shocks - a subject that we hope to investigate in a forthcoming paper. Nevertheless, analyses of single shocks do permit some intuition to be brought to bear on the issue of policy choice; they should shed some light on when particular rules are likely to perform better than others. Ranking the rules would, however, generally require an explicit objective function that specifies the weights attached to output fluctuations, inflation, and other objectives.

In the simulations reported below, we expand the set of policy rules to include not only simple and extended target-zone schemes, but nominal GNP and money targeting as well. It is implicitly assumed that nominal GNP and money targeting involve less coordination than target zones, although there is no reason to rule out the possibility that nominal GNP (or nominal domestic 
demand or money) targets might be internationally coordinated. The four policy rules can be compactly summarized as:

1. Money targeting: the short-term interest rate is aimed at a target for the monetary base; real government expenditure is exogenous.

2. Nominal GNP targeting, using the short-term interest rate. Again, government expenditure is exogenous.

3. Target zones, using the short-term interest rate; the level of world interest rates is also adjusted up or down as a function of world nominal income. Government expenditure is exogenous.

4. Blueprint proposal: As for target zones, but in addition government expenditure is aimed at a target for nominal domestic demand (i.e., absorption).

To be more precise about the implementation of the alternative policy rules, consider the following equations where lower-case variables denote logs and upper-case variables represent levels. In particular, $M$ is the monetary base ( $m$ is its logarithm), $u$ is a random shock to the demand for money, $Y$ is nominal GNP, $W Y$ is aggregate nominal income (in dollars) of industrial countries taken together, $Q$ is real GNP, $P$ is the GNP deflator, $A$ is nominal domestic absorption, $G$ is real government expenditure on goods and services, $C$ is competitiveness (the relative price of domestic to foreign output), and $R$ is the short-term interest rate. A $b$ superscript indicates baseline values, which are also assumed to be the target values of the relevant variables. Implicitly then, the simulations start from a position of equilibrium, which is disturbed by the shock being considered. The goal of each of the rules should be to return the economy as quickly and smoothly as possible to the initial equilibrium.

(1) Money targeting:

$$
R=R^{b}+13.5\left[m^{d}-m^{b}\right]
$$

where $m^{d}$ is long-run money demand, ignoring the effect of interest rates; $m^{d}$ is given by:

$$
m^{d}=p+.970 q+5.15 u
$$

(2) Nominal GNP targeting:

$$
R=R^{b}+25\left[y-y^{b}\right]
$$

(3) Target zones:

$$
R=R^{b}+\left[\left(c-c^{b}\right) / 0.1\right]^{3}+25\left[w y-w y^{b}\right]
$$

(4) Blueprint:

$$
\begin{aligned}
& R=R^{b}+\left[\left(c-c^{b}\right) / 0.1\right]^{3}+25\left[w y-w y^{b}\right] \\
& \left(G-G^{b}\right) / Q^{b}=\left(A^{b}-A\right) / A^{b}
\end{aligned}
$$


The form of the policy rules requires some explanation, especially since they differ slightly from those performed for the historical period. In general, we have attempted to follow as closely as possible the intentions of their advocates. The form selected resulted from some experimentation that identified inadequacies with alternative specifications or with feedback parameters. In particular, since policy changes have lagged effects on their targets, "instrument instability" may result if one attempts to hit the targets too closely period by period (Holbrook 1972). This applies most forcefully to the interest rate instrument, where caution needs to be exercised not to set the feedback coefficient too high.

Rule (1), for money targeting, used the same specification as in the standard version of MULTIMOD. If a money target were exactly achieved, an implication would be an explosive, sawtooth pattern for short-term interest rates. For this reason, equation (1) allows interest rates to equate the long-run demand for money (conditional on observed GNP) to the money stock target. The short-run demand for money can be written as:

$$
m=p+.1883 q-.0070 R-.0074 R_{-1}+.8058(m-p)_{-1}+u,
$$

where $u$ is an error term. Setting $m=m^{b}$ and solving for $R$, on the assumption that $R=R_{-1}$ and $m-p=(m-p)_{-1}$, yields

$$
R=-13.5\left(m^{b}-p\right)+13.1 q-69.4 u
$$

A rearrangement of this equation, on the assumption that the equation also holds in the baseline, gives rule (1) above.

Nominal GNP targeting has been proposed by Tobin (1980) and others as preferable to money targeting because it avoids an inappropriate tightening or easing of monetary policy in response to velocity shocks. The form that such a nominal GNP target might take has been discussed by Taylor (1985b), Fischer (1988), and Tobin (1980). Rule (2) was specified in terms of a target for the level of nominal GNP, rather than its rate of change, because of the potential instability of the latter identified in Taylor (1985b). Some experimentation with feedback coefficients led to a value of 25 . Since the interest rate is in percent, this implies that a 1 percent deviation from the nominal GNP target leads to a 25 basis point increase in the interest rate. Such a value yields a flatter aggregate demand schedule (in $Q-P$ space) for nominal GNP targeting than for money targeting (Taylor 1985b). Since the coefficient of real income is approximately unity in equation (1), the money rule can also be framed in terms of nominal GNP with the difference that the error in the demand-for-money equation would then also affect the setting of interest rates.

Target zones, rule (3), follow the form described in Williamson and Miller (1987) and in Edison, Miller, and Williamson (1987). There are some slight modifications relative to the historical simulations, such that the feedback rules are closer to those proposed in the "blueprint." Specifically, the width of the 
target zone is taken here to be 10 percent, not the 20 percent used in the historical simulation. The problems of nonconvergence that were present in our historical simulations did not surface here, allowing us to increase the reaction of shortterm interest rates to deviations from fundamental equilibrium exchange rates. Also, the nominal anchor for prices is the target level of world nominal income-rather than money supply targets. Note that it is the level, not the rate of change of world nominal GNP that appears in the equation, again reflecting Taylor's (1985b) findings. The feedback coefficient on world nominal GNP was taken to be the same as for domestic nominal GNP targeting.

The extended target zones or "blueprint" proposal, rule (4), contains an equation for government spending that does not hit domestic-demand targets exactly. However, since the first-year multiplier effect on output of $G$ is close to one, the rule allows approximate achievement of domestic-demand targets.

So much for the policy rules. The (transitory) shocks that we consider are the following:

(A) A shock to the demand for money - that is, to velocity-in the United States of 2 percent.

(B) An aggregate supply shock in the United States; in particular, the residual in the equation for the rate of change in the nonoil GNP deflator is increased by 2 percent.

(C) An aggregate demand shock in the United States: a positive innovation in consumption equal to 1 percent.

(D) A shift in demand towards U.S. goods, equal to 10 percent of U.S. exports.

(E) A portfolio preference shift out of U.S. dollar assets, leading to an increase in the required rate of return on dollar assets by 10 percentage points.

Each of the rules is simulated subject to each of the five shocks, one at a time. Figures 1.9 to 1.12 give the main results of interest.

The money demand shock is not plotted because the results are straightforward to describe. It is only in the case of money targeting that the money shock has any effect on policy settings and on other endogenous variables (there is a small effect of the money shock on consumption because money is a component of net wealth, but the magnitude is negligible). In the case of money targeting, the positive innovation to money demand leads to temporarily higher short-term interest rates, and as a consequence, to temporarily lower economic activity. Other rules ignore the money demand shock and maintain policy instruments unchanged; macroeconomic variables therefore remain at their equilibrium levels. This points up the superiority of these rules in the face of money demand shocks - an argument similar to that made by the advocates of nominal GNP targeting (Tobin 1980). Of course, if shifts in money demand could be identified, then the rule for targeting money could be modified to target a "shock-corrected" money stock that omitted the term $u$.

The aggregate supply shock (or cost-push inflation shock) yields a variety of responses (fig. 1.9). This shock tends to put upward pressure on the domestic output price relative to the absorption deflator, leading to some 


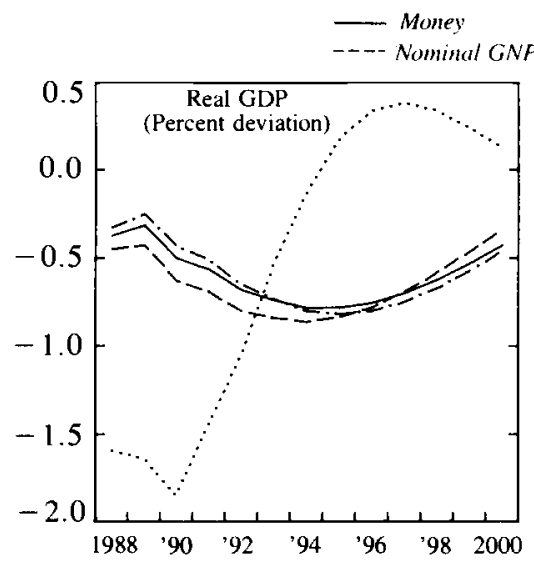

....... Blueprimt
-.-.- Target zone

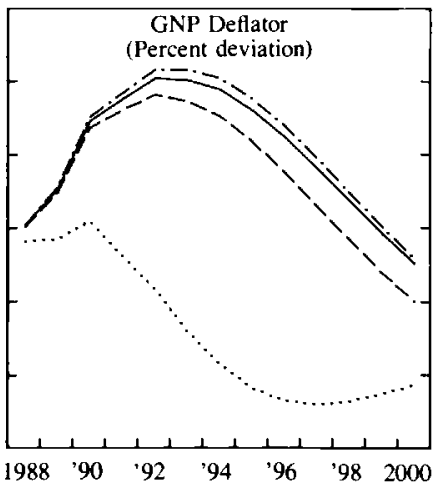

0
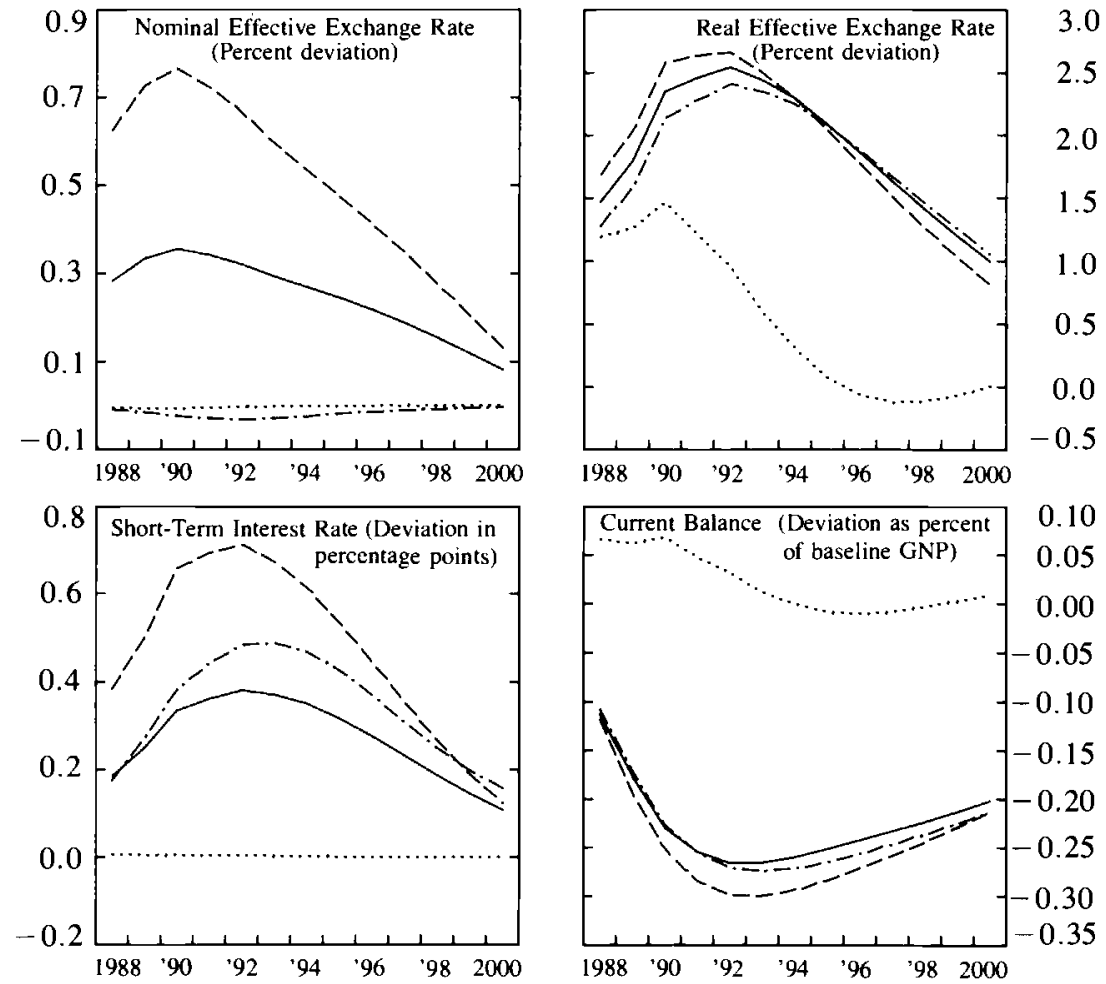

Fig. 1.9 Simulated effects of U.S. aggregate supply shock (deviations of U.S. variables from baseline) 
(short-run) stimulus to consumption as well as higher inflation. As mentioned above, the greater flatness of the aggregate demand curve under nominal GNP targeting - vis-à-vis money targeting-leads to a greater response of interest rates and hence greater short-run output losses but smaller increases in prices. Which of the two rules is preferable depends on the trade-off between the two objectives of output and price level stability, as well as on the discount rate that captures intertemporal trade-offs. ${ }^{50}$ There is also a considerable difference between responses under the target-zone and blueprint rules. Using monetary policy to counteract the real appreciation of the U.S. dollar requires lower, not higher, U.S. nominal interest rates. However, for both the target-zone and blueprint rules, there is an additional term (with admittedly an arbitrarily imposed coefficient) that tends to raise interest rates if world nominal GNP grows too fast, which is the case here. Under target zones, the result is that U.S. interest rates rise but by somewhat less than interest rates in other industrial countries. This leads to a small nominal dollar depreciation, which tends to add to inflationary pressures but limits output losses. In contrast, under the blueprint rule U.S. government spending contracts to counteract the stimulus to consumption, helping to limit the real appreciation of the dollar. The net effect on output is negative because domestic demand is close to its baseline value, but foreign demand falls. However, output is actually higher after seven years, by which time prices have returned to their baseline levels. The bottom line is that an aggregate supply shock causes a dilemma for the first three rules because one instrument has to wear two hats: that is, monetary policy has not only to resist inflationary pressures but also to neutralize output effects or resist the real exchange rate appreciation in the country experiencing the shock. ${ }^{51}$

Next, consider the aggregate demand shock, namely, a 1 percent increase in U.S. consumption (see fig. 1.10). Again, the effects differ under alternative policy rules. Absent any policy changes, such a shock will increase output and put upward pressure on prices, as well as appreciate the real exchange rate and lead to a decline in the current account. It also generates positive spillovers for the output of other countries. Since nominal GNP rises, as does the demand for money, both rules (1) and (2) cause interest rates to rise; again, given the relative steepness of the aggregate demand curves, the output and price increases are more moderate under nominal GNP targeting. Turning to the coordinated rules, the real appreciation of the U.S. dollar leads to a smaller rise in interest rates in the United States than in other industrial countries under target zones. However, by limiting the interest rate increases in the United States in response to a demand increase, this rule builds in inflationary pressures, which persist longer than for other rules. In contrast, the extra degree of freedom accorded by fiscal policy in the blueprint rule allows the aggregate demand shock to be almost completely offset by lower government spending. As a result, the output, price, and real exchange rate effects are smallest for this rule.

Figure 1.11 presents results from an aggregate demand shock that corresponds to a shift towards U.S. goods and away from other countries' goods. 

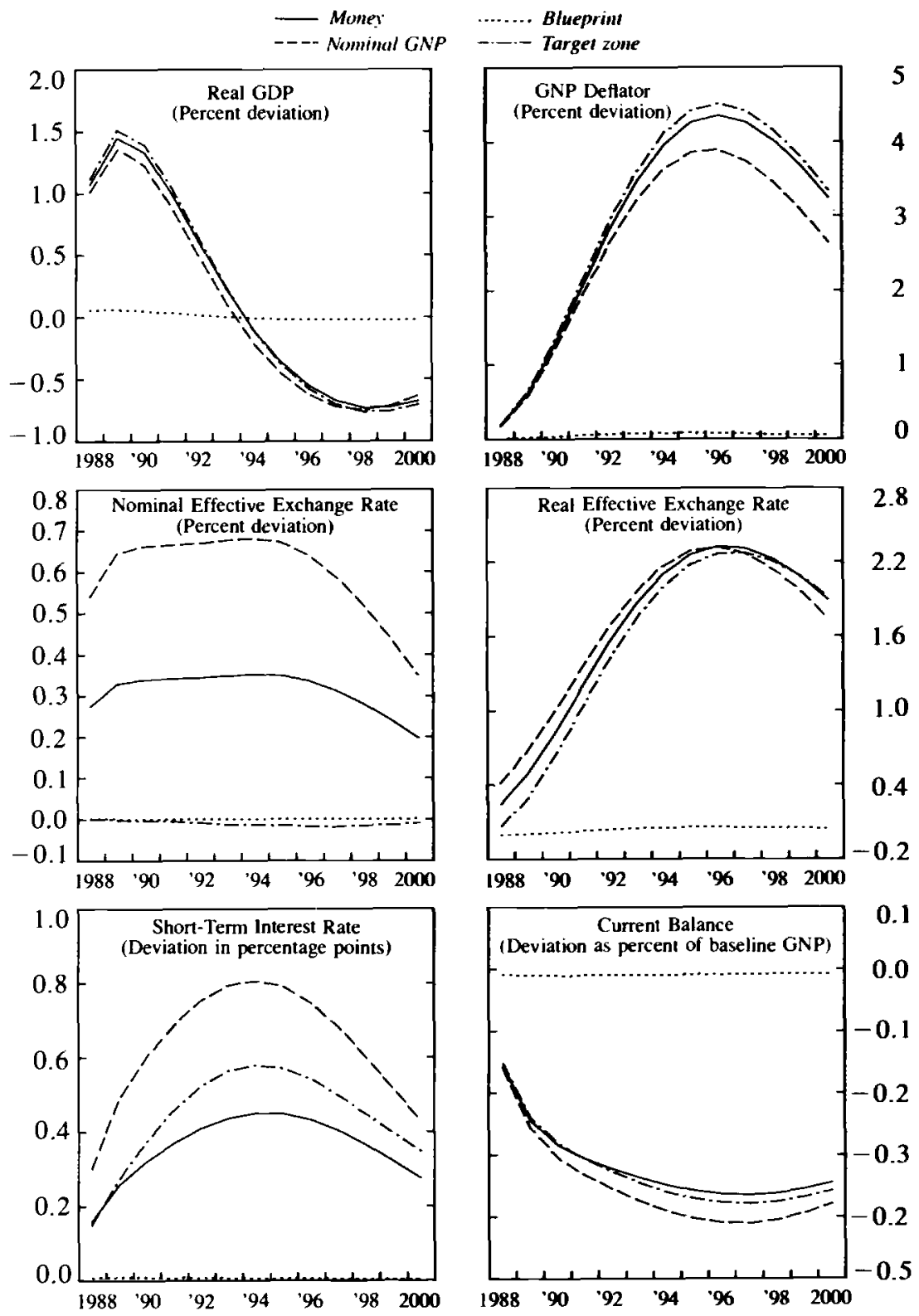

Fig. 1.10 Simulated effects of a shock to U.S. consumption (deviations of U.S. variables from baseline) 

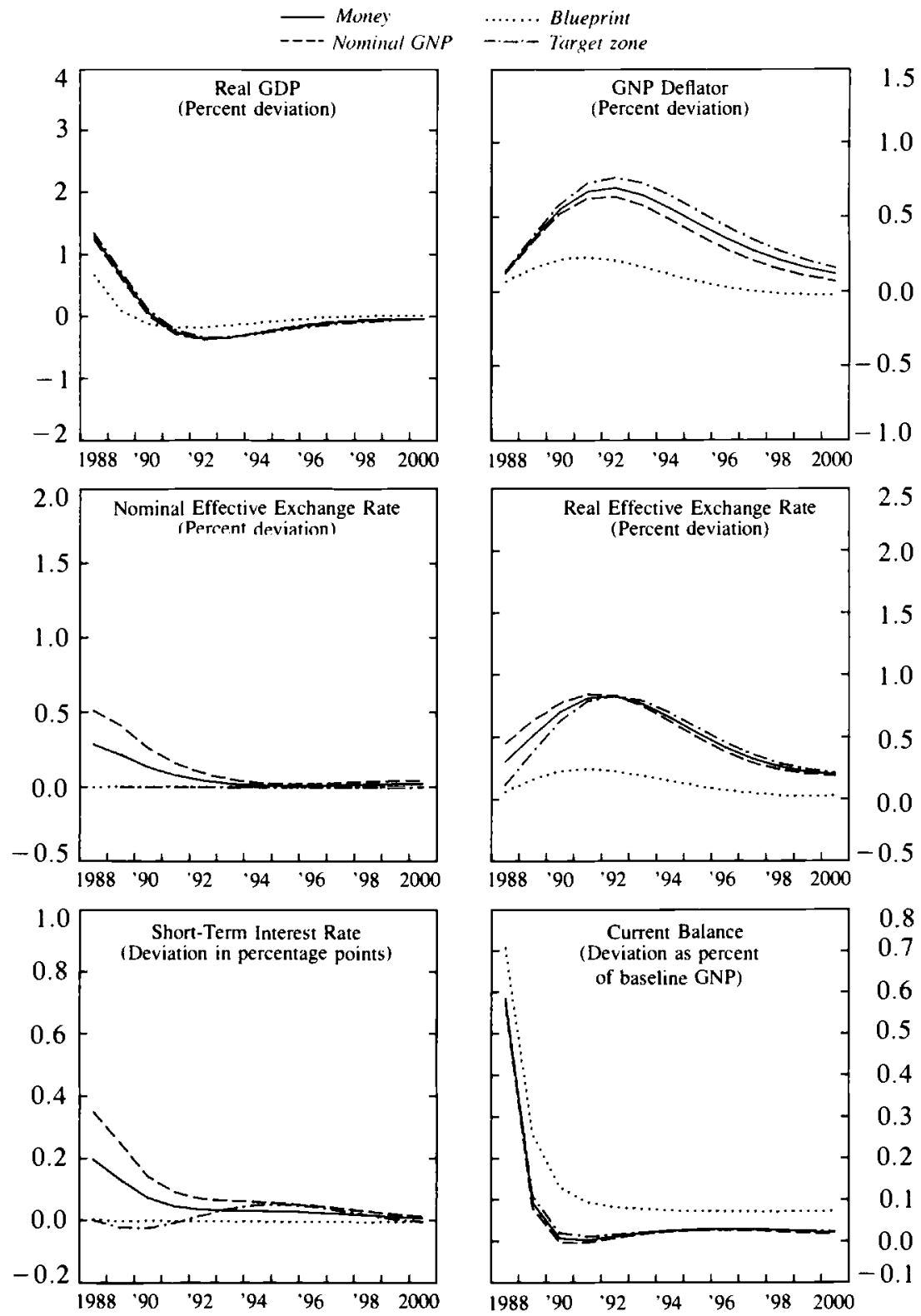

Fig. 1.11 Simulated effects of a shock to U.S. exports (deviations of U.S. variables from baseline) 
The positive shock to U.S. exports of 10 percent shows up in lower exports of other countries in proportions that correspond to their shares in world trade, ${ }^{52}$ the U.S. current account improves by some $\$ 30$ billion in the first period. For all policy rules, U.S. real output rises initially, and price increases are relatively small. The contrast is greatest in the behavior of short-term interest rates. Neither real exchange rates nor world nominal GNP change much, so that there is little effect on interest rates under target zones or the blueprint. However, money and nominal GNP targeting resist the rise in activity and prices in the U.S. by raising interest rates.

The final shock is to the exchange rate of the dollar (against the yen, the deutsche mark, and other industrial country currencies) brought about by a 10 percent increase in the required return on dollar assets. Output effects are largest for the two uncoordinated rules (money and nominal GNP targeting) and least for the coordinated rule (the blueprint) that uses both monetary and fiscal instruments. The exchange rate overshoots under all four rules, with the U.S. nominal effective exchange rate depreciating by about 15 percent in the first year. Under target zones, the GNP deflator shows no signs of stabilizing (fig. 1.12). Under the blueprint, higher domestic demand results from the income effect of higher exports; as a result, government spending must fall to achieve the nominal domestic-demand target. This leads to a greater real depreciation of the dollar in the years 1990-96 than under the other rules, and a larger current account balance.

To sum up, there are five basic conclusions that emerge from these simulations of individual shocks.

First, as in the historical simulations, monetary policy is relatively ineffective when its subsequent effects are anticipated. This conclusion seems to follow whether or not the shocks themselves are anticipated. Conversely, fiscal policy - in particular, variations in government spending - seems to be quite powerful in influencing real output, real exchange rates, and current accounts. Clearly, then, a comparison of rules that use both fiscal and monetary policy with those that just use monetary policy will favor the former. But there is a catch. The use of fiscal policy may not have the flexibility that is assumed for it in, say, the blueprint rule. It may be constrained by other objectivesincluding the need to reduce budget deficits or to limit the importance of government in the economy. As such, fiscal policy may not be able to react immediately to shocks, at least not within the one-year period assumed here.

Second, it does appear that the behavior of alternative policy rules in response to different shocks is quite different. Rules that perform best for some shocks may perform least well for others. In some cases, however, it is clear which rule dominates (or which rules dominate). For instance, if money demand shocks are prevalent, then monetary targeting is not appropriate. Somewhat surprisingly, even when portfolio preference shifts are frequent, our results do not suggest that target zones-implemented through monetary policy changes-would be preferred. Reliance on monetary policy to ensure that real exchange rates remain within target bands may not be effective. 

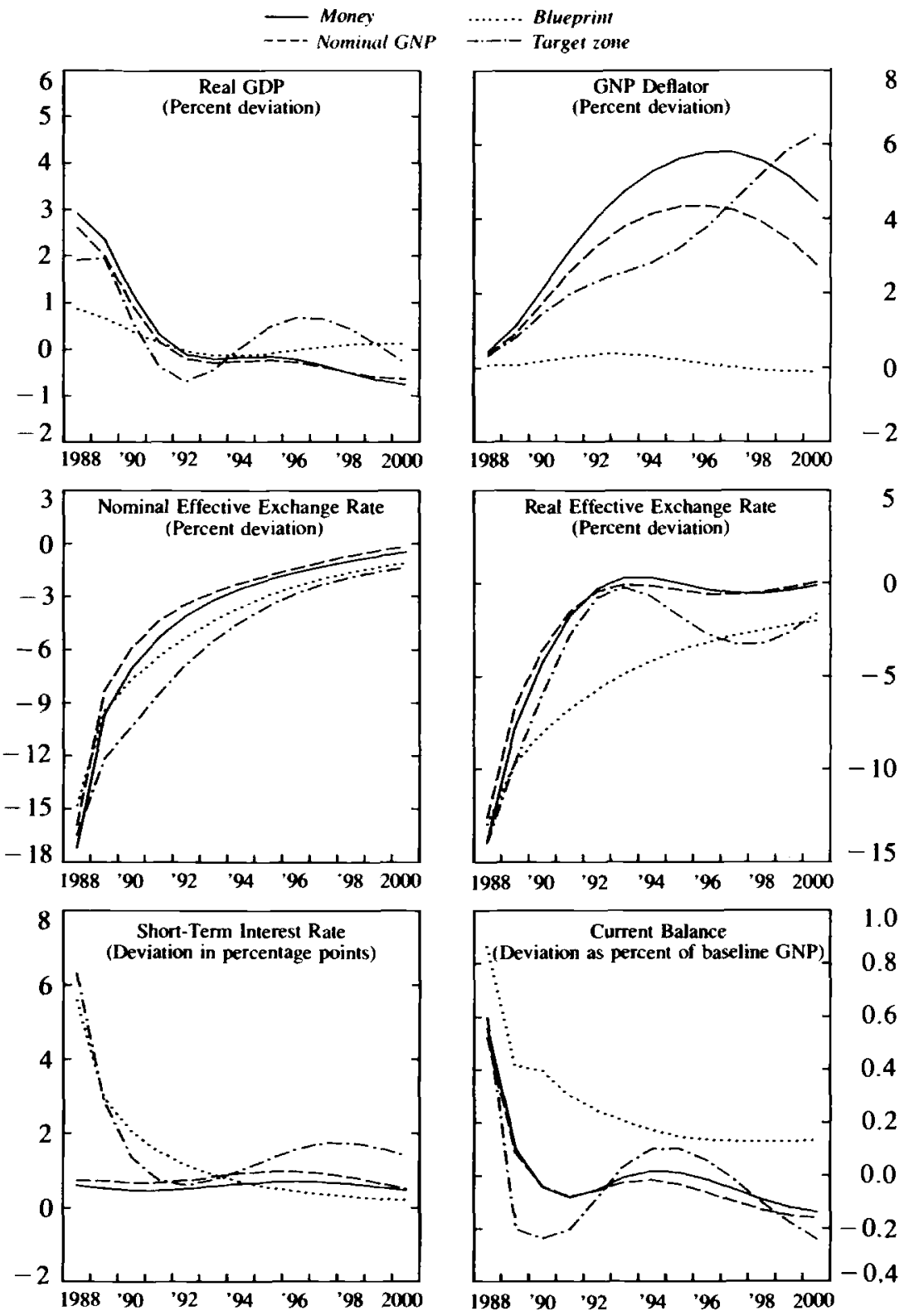

Fig. 1.12 Simulated effects of a shock to the value of the U.S. dollar (deviations of U.S. variables from baseline) 
Third, nominal GNP targeting-while it dominates money targeting if velocity shocks are prevalent- -may be subject to acute problems of instrument instability, implying that an attempt at close control would involve large swings in interest rates from period to period. Because of the relative ineffectiveness of monetary policy to affect real magnitudes in the model, using monetary policy to target nominal GNP would have to allow for large deviations from targets. It is therefore unlikely to be very precise. As a consequence, the advantages for credibility of framing policy on a single indicator are apt to be diluted by the inability of the authorities to achieve close control of that indicator. Nominal GNP targeting could also make it too easy for authorities to walk away from their targets by citing forces "beyond their control."

Fourth, the simple target-zone proposal is also subject to the ineffectiveness of monetary policy. As a result, target zones that rely solely on monetary policy do not seem capable of maintaining real effective exchange rates within bands that are even 10 percent on either side of the target. While, we have considered only arbitrary shocks, a comparison with estimated variances suggests that they are not out of line with historical experience. This relatively small impact of interest rates on real exchange rates in the model is due in large part to the twin properties that exchange rates are anchored by perfect foresight and that perfect foresight is assumed to prevail following the shocks. If the equilibrium level of the exchange rate were uncertain, or there were extrapolative expectations, then target zones might have greater effectiveness. Another important consideration is that for some shocks-in particular, a supply shock-the target zone would move monetary policy in a perverse direction. By resisting the real appreciation resulting from an inflationary shock, it would exacerbate those inflationary pressures.

Fifth and finally, target zones augmented by the use of the fiscal instrumentas outlined in the blueprint proposal-are more successful in limiting the effects of shocks. Its greater success in limiting movements away from long-run equilibrium real exchange rates derives mainly however from the use of fiscal policy. As suggested earlier, if fiscal policy is constrained by other objectives-or cannot be used flexibly - then the implied ability to counteract shocks may be illusory. Our results are an illustration of the point that it is clearly desirable to improve the flexibility of the budgetary process, whatever the objectives that guide fiscal policy.

\section{Notes}

1. Other definitions of coordination include: "decisionmaking that maximizes joint welfare and thus enables international interdependencies to be positively exploited" (Artis and Ostry 1986,14); and "agreements between countries to adjust their policies in the light of shared objectives or to implement policies jointly" (Horne and Masson 
1988, 261). A more general term is "cooperation," which includes policy coordination, but also extends to exchange of information and consultation among countries. We do not address these issues of terminology in this paper.

2. See the surveys by Artis and Ostry (1986), Cooper (1985), Fischer (1988), Hamada (1979), Horne and Masson (1988), Kenen (1987), Polak (1981), and Wallich (1984).

3. Another key issue relating to mechanisms for coordination is that of hegemonic versus more symmetric systems; on this, see Frenkel, Goldstein, and Masson (1988).

4. Evidence on the size of spillover effects from policy actions by the major industrial countries is discussed in the latter part of this section and in Table 1.1.

5. The conclusion that a monetary expansion under floating rates affects real output in opposite directions at home and abroad is associated with the Mundell-Fleming model (Mundell 1971; Fleming 1962). For a recent evaluation of this model, see Frenkel and Razin (1987a); a broader survey of the international transmission mechanism can be found in Frenkel and Mussa (1985). Econometric models are more divided on whether a monetary expansion under floating rates has negative transmission effects on real output abroad; see Helliwell and Padmore (1985) and Bryant and others (1988).

6. Corden (1986) has recently argued that there may be a case for asking large countries to slow their speed of adjustment to desired policy targets so as to dampen movements in real exchange rates that could cause difficulties for others (see sec. 1.4).

7. Another constraint on regional attempts to create more of the public good is that they may divert or discourage its production outside the region; the argument here is analogous to the concepts of "trade creation" and "trade diversion" in the customs union literature.

8. To reach this conclusion, it is necessary to assume that each player does not have sufficient policy instruments to achieve all its policy targets simultaneously, and that coordination alters the trade-offs among policy targets; see Gavin (1986). Without those assumptions, the motivation for coordination would disappear.

9. See Goldstein (1984). This is not to say that the insulating properties of floating rates are inferior to those of alternative regimes. Indeed, it is hard to see any other exchange rate regime surviving the shocks of the 1970s without widespread controls on trade and capital.

10. See Bryant and others (1988) and Helliwell and Padmore (1985) for a comparison of open-economy multipliers from different global econometric models. Frankel and Rockett (1988) illustrate the sensitivity of welfare effects of coordination to the selection of the "right" versus the "wrong" economic model.

11. See Fischer (1988). Dini (1988) goes further to argue that when the incentives to coordinate differ widely among group members, there may be a tendency for bilateral bargains to take place among those who have the most to trade

12. See Putnam and Bayne (1984). At the same time, the Bonn Economic Summit of 1978 is regarded in some quarters as illustrative of the pitfalls of coordinating macroeconomic policies when the economic outlook is changing rapidly.

13. Another example of high-frequency coordination is that among central banks of the largest countries on exchange-market intervention tactics.

14. For example, the Louvre Communiqué states that: "The United States Government will pursue policies with a view to reducing the fiscal 1988 deficit to 2.3 percent of GNP from its estimated level of 3.9 percent in fiscal 1987. For this purpose, the growth in government expenditures will be held to less than 1 percent in fiscal 1988 as part of the continuing program to reduce the share of government in GNP from its current level of 23 percent;"' see IMF (1987).

15. Because coordination of structural policies typically involves different policy instruments, individual country actions cannot-unlike in the case of coordination of 
fiscal policies - be evaluated with reference to an aggregate policy indicator that would be desirable from a global perspective.

16. This is not to deny the helpful role that harmonization of structural policiesranging from adopting similar tax provisions to implementing common regulations concerning movements of goods, labor, and capital-could play in certain circumstances.

17. Those who hold the view that international factors have minimal influence on policymaking sometimes also argue that countries' policy commitments in coordination agreements represent policies that would have occurred even in the absence of such agreements. Under this view, coordination affects only the timing of policy announcements, with countries delaying such announcements until coordination meetings so that they can present a dowry to the others.

18. See the papers in Buiter and Marston (1985).

19. As Poehl (1987, 19-20) notes: "international cooperation does not necessarily imply that all parties must agree on all details at all times. It is important that we regard it as a process of maintaining stability in our increasingly interrelated world economy. . . . The process of international cooperation may be difficult and burdensome, even frustrating at times, but there is no alternative to it."

20. It is precisely because of the risk of "collusion" among the coordinating countries that Vaubel (1985) favors decentralized decision-making.

21. It is in this context that the problems of time inconsistency and moral hazard often surface.

22. Advocates of rules also argue that once the public knows better what the authorities will do, markets will demand less of a risk premium to hold the authorities' financial obligations.

23. Kenen (1987) cites a regression of the change in the inflation rate between 1979 and 1985 on the level of the inflation rate in 1979 and a zero-one dummy variable denoting participation in the exchange rate mechanism of the EMS. The sample comprised twenty-two industrial countries. The EMS dummy variable was not statistically significant, whereas the level of the inflation rate in 1979 was. Note that this finding does not preclude a helpful role of the EMS in disinflation since participation could still have reduced the output cost of disinflation (Giavazzi and Giovannini 1988); but this is a different story.

24. As developed in Polak (1988), the need for rules to guard against the dangers of fine-tuning has receded in any case since economic policy in most industrial countries is now oriented much more toward the medium term. Fischer (1988) makes the complementary point that the state of our knowledge about the effects of monetary and fiscal policy is too rudimentary to justify policy rules. Niehans (1987) expresses doubts that rules could be relied upon to reduce international disturbances.

25. On the limitations of purchasing-power-parity rules, see Frenkel (1981).

26. Multiple indicators can reflect multiple targets and/or multiple instruments employed to reach a smaller number of targets.

27. The literature on "speculative attacks" deals with just this phenomenon; see, for example, Flood and Garber (1980).

28. See Frenkel and Goldstein (1986). This missing link between exchange rate movements and fiscal policy under target zones is being increasingly recognized. Whereas first-generation target-zone proposals spoke only of monetary policy, secondgeneration proposals have added a policy rule or guideline for fiscal policy; contrast Williamson (1985 [1983]) with Williamson and Miller (1987). Also, see the simulations of simple versus extended target-zone rules in section 1.4 .

29. See Oudiz and Sachs (1984), McKibbin and Sachs (1988), and Taylor (1985a) for evidence on the size of the gains, and Frankel and Rockett (1988) for the effects of using the "wrong" model. 
30. See Schultze (1988) and Bryant and others (1988). As an example of the difficulties associated with identifying the "counterfactual," contrast Feldstein's (1988) appraisal of the likely evaluation of exchange rates in the absence of the Plaza Agreement with that of Lamfalussy (1987).

31. Frankel and Rockett (1988), however, show that, for a set of models compared in Bryant and others (1988), gains from knowing the "true" model (assuming that one is correct) dominate gains from coordination.

32. Another recent paper, Taylor (1986), considers different exchange rate arrangements in a rational expectations model; however, only completely fixed and freely floating exchange rates are compared, and the model is limited to the seven major industrial countries.

33. The model simulations do not, however, allow for two other ways in which private sector behavior may be affected by changes in policy regimes. First, the variance of output, prices, or exchange rates may be different, leading to different degrees of substitutability among goods or assets. For example, it has been argued that the greater variability of exchange rates has led to a lower level of international trade than would have prevailed under fixed rates. Second, expectations may contain "speculative bubbles" in some circumstances, and hence may not solely reflect economic fundamentals. For example, the rise of the U.S. dollar early in 1985 despite declining interest rate differentials in favor of dollar-denominated assets is hard to explain.

34. Although simulation studies of judgmental coordinated policies are somewhat more difficult to design than analyses of rule-based proposals, a start in this direction has been made in some internal studies by Fund staff.

35 . In contrast to the industrial countries, developing countries are not assumed to face perfect capital markets. Instead, the availability of financing reflects their ability to service debt, as measured by a ratio of their inflation-adjusted interest payments to the value of their exports. It is assumed that there is an upper limit to this ratio, beyond which the risk of nonrepayment becomes high, and consequently creditors would refuse to grant further new lending. As a result of the financing constraint, imports by developing countries are also constrained, tending to reduce both consumption and investment. The constraint on financing is, however, not solely based on current developments, but also reflects an assessment of future export prospects of developing countries; expected future exports are made to be consistent with the model's solution for those future exports.

36. This is a feature that will be relaxed in future work-in particular, by imposing shocks to residuals in successive periods.

37. Labor markets do not appear explicitly in the model, but features of wage bargaining, such as those due to overlapping multiperiod contracts, are reflected in the equation estimated for inflation.

38. The properties of MULTIMOD for these policy changes are quite similar to the average for other existing multicountry models; see Fischer $(1988,16)$.

39. One strong implication of this empirical regularity is that any "assignment rule" that assigns monetary policy to the current account-for example, Williamson and Miller's (1987) blueprint-is going to face problems; on this point, see Genberg and Swoboda (1987) and Boughton (1988).

40. It is assumed here that fiscal expansion is not accommodated by an increase in money growth. Current account effects also reflect the impact of interest rate changes on net investment income.

41. Niehans $(1987,215)$ also stresses the importance of steady policies: "The first, and most promising, step to reducing international disturbances must surely be the avoidance of the policy shifts that produce them. Especially for the dominant economy, the United States, the most important part of cooperation is steadiness." 
42. The measure of real effective exchange rate is the country's manufactured export price, divided by a weighted average export price of its competitors, including developing countries. Thus, an increase indicates appreciation.

43. Corden $(1986,431)$ recognizes this to some extent: "[Coordination] means, incidentally, that if private investment in a country declines there should be some compensating increase in its fiscal deficit to modify the current account effect. It does not necessarily mean that a fiscal policy stance should be stable.'

44. The role of this variable is to give a nominal anchor to the system. The inclusion of this term is also consistent with the intent of the blueprint proposal to make the level of interest rates depend (in an unspecified fashion) on the growth of aggregate GNP.

45. In implementing the rule, the value given by Edison, Miller, and Williamson (1987) to $n, 10$ percent, was initially tried, but the model either would not solve or gave negative nominal interest rates. Consequently, a higher value, 20 percent, was used, implying a lower feedback of exchange rate misalignments on interest rates.

46. Again, we adopt Williamson's (1985) estimates of target or equilibrium real effective exchange rates merely to stay as close as possible to the original proposals. There should be no implication that we agree or disagree with those estimates. For a discussion of some of the difficulties associated with calculating equilibrium exchange rates, see Frenkel and Goldstein (1988b).

47. It should also be noted that MULTIMOD's definition of real effective exchange rates is wider than most measures, since it allows for competition from manufactures produced in developing countries.

48. It is also the case in Edison, Miller, and Williamson (1987), that real exchange rates under a target zone regime differ little from their historical values.

49. Suppose there are three time periods and that interest parity relates interest rates and exchange rates. Suppose also that the exchange rate is unchanged in the third period. In each period, the interest rate differential is equal to the appreciation that is expected for (and actually occurs in) the next period. Thus, in terms of deviations from baseline, $d_{t}=e_{t+1}-e_{t}$, where $e_{3}=0$. Then in the second period, the interest differential will have to be equal to the desired change in the exchange rate; if it is overvalued by 5 percent, interest rates will have to be 5 percentage points lower. If in the first period the exchange rate is undervalued by 5 percent, then interest rates will have to be not 5 , but 10 percentage points, higher.

50. As shown in Buiter and Miller (1982), if the model has the natural rate property, then the cumulative output losses from different disinflation policies are the same when discounting is ignored.

51. If there is no feedback of inflation onto monetary policy — such as through world nominal income-then the target-zone rule cannot be simulated in MULTIMOD because of the absence of a nominal anchor.

52. The shock is distributed using the weights that serve to allocate the world trade discrepancy in MULTIMOD. As a result, the shock to the United States is also reduced by the U.S. share of world trade, so that U.S. exports rise on impact by 8.6 percent, not the full 10 percent.

\section{References}

Artis, Michael, and Sylvia Ostry. 1986. International economic policy coordination. Chatham House Papers, no. 30, Royal Institute of International Affairs. London: Routledge and Kegan Paul. 
Bockelmann, H. 1988. The need for worldwide coordination of economic policies. Paper presented at Conference on Financing the World Economy in the Nineties, School for Banking and Finance, Tilburg University.

Boughton, James. 1988. Policy assignment strategies with somewhat flexible exchange rates. IMF Working Paper no. 88/40.

Boughton, James, and William Branson. 1988. Commodity prices as a leading indicator of inflation. IMF Working Paper no. 88/87.

Bryant, Ralph. 1987. Intergovernmental coordination of economic policies. In P. B. Kenen, ed., International monetary cooperation: Essays in honor of Henry $C$. Wallich. Essays in International Finance no. 169 (December): 4-15. Princeton: International Finance Section, Princeton University.

Bryant, Ralph, and others, eds. 1988. Empirical macroeconomics for interdependent economies. Washington, DC: Brookings Institution.

Bryant, Ralph, and Richard Portes, eds. 1987. Global macroeconomics: Policy conflict and cooperation. London: Macmillan.

Buiter, Willem, and Marcus H. Miller. 1982. Real exchange rate over-shooting and the output cost of bringing down inflation. European Economic Review 18 (May/June): $85-123$.

Buiter, Willem H., and Richard C. Marston, eds. 1985. International economic policy coordination. New York: Cambridge University Press.

Calvo, Guillermo A. 1978. On the time consistency of optimal policy in a monetary economy. Econometrica 46 (November): 1411-28.

Cooper, Richard N. 1982. The gold standard: Historical facts and future prospects. Brookings Papers on Economic Activity 1:1-45.

1985. Economic interdependence and coordination of economic policies. In R. W. Jones and P. B. Kenen, eds., Handbook of international economics, vol. 2, 1194-1234. Amsterdam: North-Holland.

1987. International economic cooperation: Is it desirable? Is it likely? Lecture presented at International Monetary Fund (October).

1988. U.S. macroeconomic policy, 1986-88: Are the models useful? In Ralph

Bryant, and others, eds., Empirical macroeconomics for interdependent economies, 255-66. Washington, DC: Brookings Institution.

Corden, W. Max. 1986. Fiscal policies, current accounts and real exchange rates: In search of a logic of international policy coordination. Weltwirtschafiliches Archiv 122 (no. 3): 423-38.

Crockett, Andrew. 1987. Strengthening international economic cooperation: The role of indicators in multilateral surveillance. IMF Working Paper no. 87/76.

Currie, David, Paul Levine, and Nicholas Vidalis. 1987. International cooperation and reputation in an empirical two-bloc model. In R. C. Bryant and R. Portes, eds., Global macroeconomics: Policy conflict and cooperation, 75-127. London: Macmillan.

Currie, David, and Simon Wren-Lewis. 1987. Conflict and cooperation in international macroeconomic policymaking: The past decade and future prospects. International Monetary Fund (December). Typescript.

Dini, Lamberto. 1988. Cooperation and conflict in monetary and trade policies. Paper presented at International Management and Development Institute, U.S.-European Top Management Roundtable. Milan, February 19.

Edison, Hali J., Marcus H. Miller, and John Williamson. 1987. On evaluating and extending the target zone proposal. Journal of Policy Modeling 9 (Spring): 199-224.

Feldstein, Martin. 1988. Distinguished lecture on economics in government: Thinking about international economic coordination. The Journal of Economic Perspectives 2 (Spring): 3-13. 
Fischer, Stanley. 1988. International macroeconomic policy coordination. In Martin Feldstein, ed., International economic cooperation, 11-43. Chicago: University of Chicago Press.

Fleming, J. Marcus. 1962. Domestic financial policies under fixed and under floating exchange rates. IMF Staff Papers 9 (November): 369-79.

Flood, Robert, and Peter Garber. 1980. Market fundamentals versus price level bubbles: The first tests. Journal of Political Economy 88 (August).

Frankel, Jeffrey, and Katherine Rockett. 1988. International macroeconomic policy coordination when policymakers do not agree on the true model. American Economic Review 78, no. 3 (June): $318-40$.

Frenkel, Jacob A. 1975. Current problems of the international monetary system: Reflections on European monetary integration. Weltwirtschaftliches Archiv 111 (no. 2): 216-21.

1981. The collapse of purchasing power parities during the 1970's. European Economic Review 16 (May): 145-65.

1982. Turbulence in the market for foreign exchange and macroeconomic policies. The Henry Thornton Lecture, City University Centre for Banking and International Finance, London.

1983. International liquidity and monetary control. In George M. von Furstenberg, ed., International money and credit: The policy roles. Washington, DC: International Monetary Fund.

1985. A note on "the good fix" and "the bad fix." European Economic Review 1-2 (June-July).

1986. International interdependence and the constraints on macroeconomic policies. Weltwirtschafliches Archiv 122 (no. 4).

Frenkel, Jacob A., and Morris Goldstein. 1986. A guide to target zones. IMF Staff Papers 33 (December): 633-70.

1988a. The international monetary system: Developments and prospects. Paper presented at the Cato Institute Conference, February 1988. Cato Journal 8 (Fall).

1988b. Exchange rate volatility and misalignment. In Financial Market Volatility. Kansas City: Federal Reserve Bank of Kansas City.

Frenkel, Jacob A., Morris Goldstein, and Paul R. Masson. 1988. International coordination of economic policies: Scope, methods, and effects. In Wilfried Guth, ed., Economic Policy Coordination, 149-91. Washington, DC: International Monetary Fund.

Frenkel, Jacob A., and Michael Mussa. 1985. Asset markets, exchange rates and the balance of payments. In R. W. Jones and P. B. Kenen, eds., Handbook of international economics, vol. 2, 679-747. Amsterdam: North-Holland.

Frenkel, Jacob A., and Assaf Razin. 1987a. The Mundell-Fleming model: A quarter century later. IMF Staff Papers 34 (December) 567-720.

1987b. Fiscal policies and the world economy. Cambridge, MA: MIT Press.

Gavin, Michael. 1986. Macroeconomic policy coordination under alternative exchange rate regimes. Federal Reserve Board (September). Typescript.

Genberg, Hans, and Alexander Swoboda. 1987. The current account and the policy mix under flexible exchange rates. IMF Working Paper no. 87/70.

Ghosh, Atish R., and Paul R. Masson. 1988. International policy coordination in a world with model uncertainty. IMF Staff Papers 35 (June): 230-58.

Giavazzi, Francesco, and Alberto Giovannini. 1988. Interpreting the European disinflation. The role of the exchange rate regime. Informacion Comercial Espanola (May).

Goldstein, Morris. 1980. Have flexible exchange rates handicapped macroeconomic policy? Special Papers in International Economics no. 14 (June). Princeton: Princeton University Press. 
1984. The exchange rate system: Lessons of the past and options for the future. IMF Occasional Paper no. 30 (July).

Hamada, Koichi. 1979. Macroeconomic strategy and coordination under alternative exchange rates. In R. Dornbusch and J. Frenkel, eds., International economic policy: Theory and evidence, 292-324. Baltimore: Johns Hopkins University Press.

Helliwell, John F., and Tim Padmore. 1985. Empirical studies of macroeconomic interdependence. In R. W. Jones and P. B. Kenen, eds., Handbook of international economics, vol. 2, 1107-51. Amsterdam: North-Holland.

Henderson, Dale. 1979. Financial policies in open economics. American Economic Review 69 (May): 232-39.

Holbrook, Robert S. 1972. Optimal economic policy and the problem of instrument instability. American Economic Review 62 (March): 57-65.

Holtham, Gerald, Giles Keating, and Peter Spencer. 1987. EMS: Advance or face retreat. London: Credit Suisse First Boston Ltd.

Horne, Jocelyn, and Paul R. Masson. 1988. Scope and limits of international economic cooperation and policy coordination. IMF Staff Papers 35 (June): 259-96.

IMF. 1974. Documents of the Committee of 20. Washington, DC: International Monetary Fund.

1986. IMF Survey (May 19): 157

1987. IMF Survey (March 9): 73.

Jurgensen, Philippe. 1983. Report of the working group on exchange market intervention. Washington, DC: U.S. Treasury.

Kenen, Peter B. 1987. Exchange rates and policy coordination. Brookings Discussion Paper no. 61 (October). Washington, DC: Brookings Institution.

Kydland, F., and E. Prescott. 1977. Rules rather than discretion: The inconsistency of optimal plans. Journal of Political Economy 85 (June): 473-91.

Lamfalussy, Alexandre. 1987. Current account imbalances in the industrial world: Why they matter. In P. B. Kenen, ed., International monetary cooperation: Essays in honor of Henry $C$. Wallich. Essays in International Finance no. 169 (December): 31-37. Princeton: International Finance Section, Princeton University.

Masson, Paul R., and others. 1988. MULTIMOD: A multi-region econometric model. Staff studies for the world economic outlook (July). Washington, DC: International Monetary Fund.

McKibbin, Warwick J., and Jeffrey D. Sachs. 1988. Coordination of monetary and fiscal policies in the industrial countries. In Jacob A. Frenkel, ed., International aspects of fiscal policy, 73-113. Chicago: University of Chicago Press.

Mundell, Robert A. 1971. The dollar and the policy mix. Essays in International Finance no. 85 (May). Princeton: Princeton University Press.

Mussa, Michael. 1981. The role of official intervention. Occasional Paper no. 6. New York: Group of Thirty.

Niehans, Jurg. 1987. Generating international disturbances. In Y. Suzuki and M. Okabe, eds., Toward a world of economic stability: Optimal monetary framework and policy, 181-218. Tokyo: University of Tokyo Press.

Oudiz, Gilles, and Jeffrey D. Sachs. 1984. Macroeconomic policy coordination among the industrial economies. Brookings Papers on Economic Activity 1: 1-75.

Poehl, Karl Otto. 1987. Cooperation-A keystone for the stability of the international monetary system. First Arthur Burns Memorial Lecture, at the American Council on Germany, New York (November).

Polak, Jacques J. 1981. Coordination of National Economic Policies. Occasional Paper no. 7. New York: Group of Thirty.

1988. Economic policy objectives and policymaking in the major industrial countries. In Wilfried Guth, ed., Economic policy coordination, 1-43. Washington, DC: IMF.

Poole, William. 1970. Optimal choice of monetary policy instruments in a simple stochastic macro model. Quarterly Journal of Economics 84 (May): 197-216. 
Putnam, Robert D., and Nicholas Bayne. 1984. Hanging Together: The Seven-Power Summits. Cambridge, MA: Harvard University Press.

Putnam, Robert D., and C. Randall Henning. 1986. The Bonn summit of 1978: How does international economic policy coordination actually work? Brookings Discussion Papers in International Economics no. 53 (October). Washington, DC: Brookings Institution.

Rogoff, Kenneth. 1985. Can international monetary policy cooperation be counterproductive? Journal of International Economics 18 (May): 199-217.

Schultze, Charles. 1988. International macroeconomics coordination-Marrying the economic models with political reality. In Martin Feldstein, ed., International Economic Cooperation, 49-60. Chicago: University of Chicago Press.

Tanzi, Vito. 1988. Fiscal policy and international coordination: Current and future issues. Paper presented at Conference on Fiscal Policy, Economic Adjustment, and Financial Markets. Boconni University, January 27-30.

Tanzi, Vito, and Teresa Ter-Minassian. 1987. The European monetary system and fiscal policies. In Sijbren Cnossen, ed., Tax coordination in the European community, ch. 13. Series on International Taxation no. 7. Boston: Kluwer Law and Taxation Publishers.

Taylor, John. 1985a. International coordination in the design of Macroeconomic policy rules. European Economic Review 28 (June-July): 53-81.

$1985 \mathrm{~b}$. What would nominal GNP targeting do to the business cycle? In K. Brunner and A. H. Meltzer, eds., Understanding monetary regimes. CarnegieRochester Conference Series on Public Policy 22: 61-84.

1986. An econometric evaluation of international monetary policy rules: Fixed versus flexible exchange rates. Stanford University. Typescript.

Tobin, James. 1980. Stabilization policy ten years after. Brookings Papers on Economic Activity 1: 19-71.

1987. Agenda for international coordination of macroeconomic policies. In

P. B. Kenen, ed., International monetary cooperation: Essays in honor of Henry $C$. Wallich. Essays in International Finance no. 169 (December): 61-69. Princeton: International Finance Section, Princeton University.

U.S. Congress. 1982. Report to the congress of the commission on the role of gold in the domestic and international monetary systems. Washington, DC: Government Printing Office (March).

Vaubel, Roland. 1985. International collusion or competition for macroeconomic policy coordination? A restatement. Recherches Économiques de Louvain 51 (December): 223-40.

Wallich, Henry C. 1984. Institutional cooperation in the world economy. In Jacob Frenkel and Michael Mussa, eds., The world economic system: Performance and prospects, 85-99. Dover, MA: Auburn House.

Williamson, John. 1985[1983]. The exchange rate system. 2d ed. Policy Analyses in International Economics no. 5. Washington, DC: Institute for International Economics.

Williamson, John, and Marcus H. Miller. 1987. Targets and indicators: A blueprint for the international coordination of economic policy. Policy Analyses in International Economics no. 22 (September). Washington, DC: Institute for International Economics.

\section{Comment Martin Feldstein}

Jacob Frenkel and his colleagues at the International Monetary Fund have presented not just an interesting paper, but what are essentially two very interesting, but quite incompatible, papers. In the first of these, they analyze

Martin Feldstein is the George F. Baker Professor of Economics at Harvard University and President and Chief Executive Officer of the National Bureau of Economic Research. 
different types of macroeconomic coordination, summarizing the arguments for and against coordination, but focusing on the arguments in favor of coordination of the type now practiced by the G-7 finance ministers: discretionary ad hoc agreements, the absence of any explicit policy response rules, a vague multitarget process, and an emphasis on exchange rate targets.

In their second "paper,' the authors present a fascinating empirical analysis of the results of five possible ways to formalize exchange rate stabilization and, more generally, macroeconomic coordination. My reading of their evidence is that none of these rules would lead to satisfactory economic performance. In the historic simulations that they present, the proposed rules lead to wild fluctuations of exchange rates or interest rates. Moreover, the fiscal policies that would be required to stabilize real exchange rates would call upon the Federal Republic of Germany and Japan to have budget deficits of more than 8 percent of GNP. The single-shock simulations also give little reason to be sanguine about coordination efforts unless fiscal policy can be coordinated, something that clearly has not been achieved between the United States and Germany and, as the authors note, has not even been achieved among the countries that participate in the EMS.

I describe these as two incompatible papers because I do not see how, given the evidence of these simulations, Frenkel, Goldstein, and Masson (FGM) can be at all sanguine about the usefulness of macroeconomic coordination and attempts at exchange rate stabilization.

Indeed, even without their simulation analyses, I cannot agree with their optimistic view of the potential advantages of macroeconomic coordination. There may be a case for quiet information exchange and discussion of the type that takes place at the monthly meetings of the Bank for International Settlements or the periodic meetings of the OECD's Working Party 3. But the attempts to go beyond the exchange of information and to coordinate macroeconomic policy and exchange rates in the manner of the G-7 meetings is, I believe, unwise.

It could, of course, be argued that the FGM empirical evidence against explicit coordination is not very persuasive because the econometric model (IMF's MULTIMOD) is, as the authors stress, still very preliminary. Moreover, the perfect foresight character of the model and the assumption that announcements of government policies are completely believed are both substantial departures from reality. And, although the authors refer to the Lucas (1976) critique, they do not deal with it even though it is particularly important in the present context, in which the proposed policies are very different in character from the ones that prevailed during the period that generated the data on which their estimates are based.

But the inadequacy of existing modeling capability should hardly be comfort to advocates of coordination. If the best model that the IMF has is still preliminary and far from reliable, it is hard to see how governments can have the analytic capability to do macroeconomic coordination. 
Although FGM offer the common observation that the growth of trade has increased economic interdependence, the evidence that they present in table 1.1 shows that the interdependence is so small it can hardly be used to support the case for U.S. participation in a macroeconomic coordination process. For example, if Germany and Japan both increase their government spending by 1 percent of GNP, the impact in the United States would be a real GNP rise of only 0.2 percent or about $\$ 10$ billion.

The large fiscal changes that would be needed to have any substantial real impact are likely to be strongly resisted unless they also serve domestic goals (in which case they would be achieved without the coordination process). The authors implicitly recognize this when they say that fiscal instruments may enter the social welfare functions of countries. And well they should, since changes in tax rates alter excess burdens and income distribution; changes in government spending increase or decrease benefits to current citizens; and changes in deficits imply changes in future debt service, with the corresponding excess burdens.

I believe that FGM are also overly optimistic about the nature of the G-7 agreements. They write as if they believe that the official communiqués issued reflect what ministers actually believe and what governments will actually do. A more accurate assessment would regard the G-7 communiqués as politically convenient declarations. Let us look at the two examples which FGM select to illustrate their case.

In 1978, at the Bonn Summit, Germany and other governments committed to accelerate their growth rates in exchange for a commitment by the United States to come to grips with its inflation problem. In fact, U.S. inflation continued to rise for three more years. It was eighteen months after the Bonn Summit that Paul Volcker persuaded the Federal Reserve and President Carter to impose a tighter monetary policy, and even this was soon reversed under pressure from President Carter. The Reagan administration's support in 1981 for tough anti-inflationary policies was totally unrelated to the earlier Summit discussions.

FGM also cite the specific promise of the United States at the February 1987 Louvre meeting of the G-7 finance ministers. The communiqué not only promised a reduction of the U.S. budget deficit, but also specified that it would be reduced to 2.3 percent of GNP in fiscal year 1988 by containing the growth of government spending. This was, of course, only a restatement of the recently proposed Reagan budget for FY1988 and not at all a reflection of the likely outcome of the upcoming negotiations with Congress. In the end, the FY 1988 deficit was 3.2 percent of GNP, despite surprisingly fast economic growth between 1987 and 1988 . The actual deficit rose between these two years.

Although I understand that there are ambiguities in interpreting economic policies, I doubt that any budget action that the United States has taken since the Louvre meeting was the result of its international agreements. Moreover, 
the American system of government makes it clear that the U.S. Treasury secretary cannot reliably promise any change in either monetary or fiscal policy.

I am also very skeptical of the credit that the authors give to the 1985 Plaza Accord (see sec. 1.4) for either the reduction of the dollar or the reduction of protectionist pressures in the United States. Even a cursory examination of the exchange rate data shows that the value of the dollar fell as rapidly in the six months before the Plaza meeting as it did in the six months after the Plaza meeting. Although it is hard to assess what protectionist pressures would have been if the dollar had not fallen, there can be no doubt that the 1988 trade bill is a remarkably protectionist piece of legislation.

In my judgment the G-7 summits and finance ministers, meetings and communiqués are basically empty political gestures that are useful to the political figures involved, but of no substantive importance. That in itself is probably a good thing, because effective coordination of policy would probably have increased inflationary pressures during the past several years. For example, the pressure on the United States to reduce the value of the dollar during 1982 through 1984, if it had been effective, would have forced the Federal Reserve to adopt a more inflationary monetary policy.

There are several other ways in which the current G-7 process is actually counterproductive. ${ }^{1}$ First, the emphasis on macroeconomic coordination and exchange rate management deflects attention from other less glamorous areas where cooperation could be helpful, including the LDC debt problem, trade conflicts, and cross-border environmental issues.

Second, the emphasis on interdependence and the responsibilities of "other countries" to contribute to the solution of our macroeconomic problems causes antagonism. Now the United States tells other countries that they must change their monetary and fiscal policies to assist us or accept the adverse consequences that we can impose on them. Secretary Baker repeatedly asserted in 1986 that if Germany and Japan did not pursue more expansionary policies, the United States would punish them by depressing the value of the dollar and thus the trade balances of those countries. How will Americans react if the Japanese tell us in some future year that we must change our domestic policies to help them or suffer the consequences that they can impose on us?

Third, the emphasis on interdependence provides a political excuse for inaction. The coordination process provides domestic policy with a handy scapegoat. If the U.S. economy performs badly, the blame is shifted from domestic policies to the actions of Germany and Japan.

Finally, business and portfolio investors can be frightened into inappropriate action by the notion that our economy will suffer unless we have active cooperation from other major industrial countries. That sentiment contributed to the stock market crash in October 1987. Fortunately, immediately after the crash both Alan Greenspan and James Baker indicated that the value of the 
dollar would no longer be a goal of economic policy, which would instead focus on the domestic economy.

As these comments indicate, my reading of the paper by Frenkel, Goldstein, and Masson has only reinforced my skepticism about international macroeconomic coordination. The analytic arguments offer no new reasons to favor integration; the measures of interdependence show that we can easily achieve the desired shifts in macroeconomic stimulus without foreign assistance; and the simulation results show that no policy reaction process that FGM could devise would improve either the historic performance of the world's economy or the prospective reaction to individual shocks.

Quiet discussions of economic policy among key government officials of the major countries are no doubt a good thing. Times may even exist when joint action is clearly of mutual interest. But the current public proclamations of macroeconomic coordination as a regular aspect of policy and formal schemes for exchange rate management are a bad idea. There is nothing in this paper to make us believe otherwise.

\section{Note}

1. For a more complete statement of these views, see $\mathbf{M}$. Feldstein, Distinguished lecture on economics in government: Thinking about international economic coordination. Journal of Economic Perspectives 2 (Spring 1988): 3-13.

\section{Comment William H. Branson}

This paper by Jacob Frenkel, Morris Goldstein, and Paul Masson (FGM) is broad-ranging and informative. It thoroughly covers the rationale, scope, and mechanisms of coordination, or rather, as I argue below, cooperation, as seen from the perspective of the IMF or the G-7. This is in contrast to much of the literature on coordination in economics, which focuses on technical aspects of game theory. In a sense, here we see coordination as perceived by practitioners who are fully aware of the technical issues that are involved in its analysis, but leave them submerged. As a result, the paper is very readable and will be widely read. The paper also gives us a nice exercise in the use of the IMF's MULTIMOD world model to analyze alternative policy regimes. This, too, is clear and readable, and provides good exposure for MULTIMOD. Thus both the discussion of coordination issues and the simulation study are useful additions to our knowledge.

William H. Branson is the Jacob Viner Professor of International Economics at Princeton University, and Director of the Program in International Studies at the NBER. 
I will begin with FGM's definition of coordination, and put it in a broader context of international economic cooperation. FGM, in my view, generally discuss the looser concept of cooperation rather than coordination as the authors define it. As I go through my comments on the paper's substance, I will point out why this is my view. This does not detract at all from the value of the paper's discussion of cooperation, but it does refocus the paper somewhat. At the end of the comment, I will come back to some thoughts about why economists have such peculiar difficulties with the concept of coordination.

The paper begins with the well-known definition by Henry Wallich of coordination as "a significant modification of national policies in recognition of international economic interdependence." This is a useful definition, which the following quotation from Lamberto Dini $(1988,1)$ puts into a broader context:

I find it useful ... to distinguish between cooperation and coordination. Cooperation basically involves information exchange, consultation among authorities, and possibly common assessments of the international repercussions of national policies. Coordination means that policy-makers in a number of countries agree on common objectives and together take joint policy decisions that differ from those they would have taken on their own. Conflict is . . . the opposite of coordination. It may arise . . . when no consideration is given to the international dimension of national policies. . . We can view international cooperation as a continuum ranging from coordination, the highest level of cooperation, to conflict, when cooperation breaks down.

In the context set by Dini, the FGM paper is mainly about cooperation.

The discussions in the numerous international forums that are examined in the paper are examples of cooperation, using the Dini and the Wallich definitions. The argument for an ongoing process is a persuasive one, if applied to cooperation, with occasions within the process that call for coordinated action. The discussion of rules versus discretion seems to be half about coordination (rules) and half about cooperation (discretion), and the choice between single and multiple indicators is applicable to an ongoing process of cooperation.

The simulations using MULTIMOD provide some interesting and surprising results. FGM's table 1.1 shows the basic policy multipliers from MULTIMOD solutions for the United States, Japan, and the Federal Republic of Germany. The GDP results show minimal interdependence between the United States and Germany, and substantial effects on Japan from the United States, but not vice versa. One can see here the source of some results that indicate that the gains from coordination would be small. It would be interesting to see these multipliers with Germany replaced by a European aggregate. I would expect to see larger spillovers involving Europe in that case. 
The second set of interesting results comes from the exercise in which the policy variables in the history are smoothed in the simulation, on the supposition that smoother policy would give smoother outcomes. This supposition is suspect on at least two grounds. First, there were substantial exogenous shocks, such as oil price changes, during the 1974-87 simulation period. Second, with forward-looking expectations, which MULTIMOD features, the announcement of a gradual policy shift in the future should cause interest rates and exchange rates to jump at the time of the announcement. We saw this effect with the Reagan budget program in 1981. As FGM note, the result of the simulations is the opposite of the supposition. In FGM's table 1.2 we see that smoothing policy has little effect on the mean outcomes for the target variables, but that it generally increases the standard deviations! Thus during the $1974-87$ period, on average, monetary and fiscal policy were stabilizing, according to MULTIMOD. This is an encouraging result for new-Keynesian activists.

Next, FGM go on to simulations of target zones and the Williamson-Miller blueprints. The most notable result here is the effect of the blueprints on current account balances, shown in FGM's figure 1.8. FGM note that the target zones and blueprints reduce the current imbalances of the three major countries, but the effect on the United States is very small. My impression from figure 1.8 is that the target zones or blueprints shift the counterpart of the U.S. deficit from Germany and Japan to the other G-7 countries. The last set of simulations shows the effects of various single shocks in the United States under four alternative policy rules. The results are shown in FGM's figures 1.9-1.12. The blueprint results mainly stand out due to the stabilizing effects of the flexible U.S. fiscal policy that they assume. Since MULTIMOD appears to be a new-Keynesian model, this is not surprising. But the results do emphasize how important this assumption about fiscal policy is for the operation of the blueprints.

Finally, I return to the question of why economists have such difficulty with the idea of coordination. After all, theorists and practitioners in many disparate fields find coordination to be the natural state of affairs. Arms negotiators, international health officials, air traffic controllers, museum curators, and even the International Olympic Committee all coordinate; why shouldn't economic policymakers? I think an indication of the resolution of this seeming conundrum can be found in the two quotations that begin the FGM paper.

Martin Feldstein focuses on a very narrow scope for coordination, namely macroeconomic policy, and the possibility that international coordination will distract attention from the effort needed to get domestic policy right. Presumably the cost of this distraction is larger than the small gains from macroeconomic policy coordination, in Feldstein's view. James Tobin takes a wider view, with economic warfare within his horizon. He, like the international health officials, thinks some form of coordination is almost inevitable. 
The economist's problem seems to come from narrowing the scope for coordination so much that the gains from trade are virtually eliminated. Why do we do this? Perhaps, in order to reduce the problem to a size that is manageable with the available tools, usually game theory, we have to squeeze it down so much that the substance vanishes. This difficulty shows up in FGM's inability to stick to their own definition of coordination. To make things interesting, as they do, and go beyond a game-theoretic analysis, they properly expand their horizon to cooperation, as Lamberto Dini defined it. The next step would be an analysis of the optimal scope for coordination.

\section{Reference}

Dini, Lamberto. 1988. Cooperation and conflict in monetary and trade policies. International Management and Development Institute, U.S.-European Top Management Roundtable. Milan, February 19. 